\title{
Description of the skeleton of the fossil beaked whale Messapicetus gregarius: searching potential proxies for deep-diving abilities
}

\author{
Benjamin Ramassamy ${ }^{1,2}$, Olivier Lambert ${ }^{3}$, Alberto Collareta ${ }^{4,5}$, Mario Urbina $^{6}$, and Giovanni Bianucci ${ }^{4}$ \\ ${ }^{1}$ Natural History Museum of Denmark, University of Copenhagen, Copenhagen, 1350, Denmark \\ ${ }^{2}$ Department of Natural History and Palaeontology, the Museum of Southern Jutland, Gram, 6100, Denmark \\ ${ }^{3}$ D.O. Terre et Histoire de la Vie, Institut royal des Sciences naturelles de Belgique, Brussels, 1000, Belgium \\ ${ }^{4}$ Dipartimento di Scienze della Terra, Università di Pisa, Pisa, 56126, Italy \\ ${ }^{5}$ Dottorato Regionale Pegaso in Scienze della Terra, via Santa Maria 53, Pisa, 56126, Italy \\ ${ }^{6}$ Departemento de Paleontología de Vertebrados, Museo de Historia Natural-Universidad, Lima, 15072, Peru
}

Correspondence: Benjamin Ramassamy (fbd313@alumni.ku.dk)

Received: 30 July 2017 - Revised: 17 November 2017 - Accepted: 21 November 2017 - Published: 16 January 2018

\begin{abstract}
Ziphiidae (beaked whales) are a successful family of medium- to large-sized toothed whales. Their extant members perform regular deep dives beyond the photic zone to forage for cephalopods and fish. Conversely, extinct longsnouted stem ziphiids are interpreted as epipelagic predators. However, some aspects of this hypothesis remain unclear due to the lack of clear morphological proxies for recognizing regular deep divers.

We compared the forelimb, neck, and pterygoid sinus system of the fossil ziphiid Messapicetus gregarius with those of other odontocetes to evaluate the potential of these body regions as proxies to assess deep-diving specialization. The reconstructed musculature of the neck and forelimb of M. gregarius was also compared with that of other odontocetes. We also quantified variation in the proportions of the forelimb and the hamular fossa of the pterygoid sinus (HF) using 16 linear measurements. The degree of association between diving behaviour in extant odontocetes and these measurements was evaluated with and without phylogenetic correction.

Reconstruction of the neck musculature suggests that M. gregarius possessed a neck more flexible than most extant ziphiids due to the lower degree of fusion of the cervical vertebrae and the large insertions for the M. longus colli and $\mathrm{Mm}$. intertransversarii ventrales cervicis. While neck rigidity might be related to deep diving, differences in neck flexibility among extant ziphiids indicate a more complex functional interpretation. The relationship between forelimb morphology and diving behaviour was not significant, both with and without phylogenetic correction, suggesting that it cannot be
\end{abstract}

used to assess deep-diving abilities with the parameters considered here. Measurements of the HF revealed successful to evaluate deep-diving abilities in odontocetes, with an enlargement of this structure in deep divers. Considering other evidence that suggests an epipelagic behaviour, we propose different scenarios to explain the observation of an enlarged HF in M. gregarius: (1) this species may have fed at different depths; (2) it performed deep dives to avoid potential predators; or (3) the enlarged HF and deep-diving habitat correspond to an ancestral condition, with $M$. gregarius returning to a more epipelagic habitat.

\section{Introduction}

Ziphiidae (beaked whales) are a successful family of medium- to large-sized odontocetes (toothed cetaceans) currently represented by at least 22 extant species in 5 genera (Dalebout et al., 2014). The best-known modern ziphiids perform regular dives to reach foraging grounds up to $3000 \mathrm{~m}$, beyond the photic zone, where they capture cephalopods, crustaceans, and bathypelagic fish via suction (Clarke, 1996; Heyning and Mead, 1996; Hooker and Baird, 1999; Johnson et al., 2004; MacLeod et al., 2003; Minamikawa et al., 2007; Schorr et al., 2014; Tyack et al., 2006).

Accordingly, Ziphiidae share a unique set of morphological, physiological, and behavioural adaptations allowing them to optimize the travel time to reach their foraging grounds. First, extant ziphiids travel from the surface in 
a vertical position with a slow fluke rate at which the animal is gliding between each fluking period (Tyack et al., 2006). Furthermore, their shortened and fused neck stabilizes their head to maintain a streamlined body during the descent phase (Buchholtz, 2001; Lambert et al., 2013). Likewise, their reduced flipper tucks in an indentation along the body wall to decrease drag forces (Mead et al., 1982). Rommel et al. (2006) have noticed that Ziphius cavirostris possesses a flexible rib cage composed of 7 double-headed ribs (vs. 4-5 in Tursiops truncatus), 5-6 sternebrae (3-4 in T. truncatus), and cartilaginous sternal ribs (composed of bone in T. truncatus). The authors have suggested these structures to be related to changes in the thorax anatomy in response to lung collapse during deep dives. Finally, extant ziphiids exhibit an enlarged hamular fossa for the pterygoid sinus (HF), where they store large amounts of air. The pterygoid sinuses are connected to the tympanic cavity. This region around the middle ear bones needs to be surrounded by air to provide acoustic isolation, binaural hearing, and efficient functioning of the ossicular chain (Cranford et al., 2008). At great depth, the large volume of the pterygoid sinuses is thought to be squeezed by the high hydrostatic pressure toward the tympanic cavity, thus permitting ziphiids to hear and use directional echolocation during deep dives (Cranford et al., 2008; Lambert et al., 2013).

Unlike extant beaked whales, some of the long-snouted stem ziphiids (Messapicetus spp. and Ninoziphius platyrostris) are interpreted as epipelagic predators (Lambert et al., 2015). This hypothesis is based on three arguments. First of all, remains of these species come from platform or coastal deposits, while many fossils of crown ziphiids are recovered in deep-sea deposits (Bianucci et al., 2008, 2013, 2016c; Lambert et al., 2015). Furthermore, the preserved fossil regurgitation of a specimen of $M$. gregarius, composed of numerous epipelagic fish, suggests that this stem ziphiid foraged in shallower grounds than extant ziphiids (Lambert et al., 2015). Finally, stem ziphiids lack some of the morphological adaptations related to suction feeding and deep diving observed in extant species (Lambert et al., 2015). The proportionally longer humerus of Messapicetus gregarius suggests that its flipper was longer and thus more subject to drag forces during descent and ascent phases. The lower number or lack of fused cervical vertebrae observed in several adult stem ziphiid specimens indicates a more flexible neck as compared to extant ziphiids. The elongated rostrum of some stem ziphiids bearing numerous functional teeth was less specialized for suction feeding, a feeding strategy often related to deep diving among extant odontocetes (de Muizon, 1984; Lambert et al., 2013, 2015).

Nonetheless, some aspects of this hypothesis remain unclear. Concerning the humerus morphology of $M$. gregarius, only deep-diving extant ziphiids were used for comparison. Including other non-deep-diving odontocetes is necessary to confirm that the elongation of the humerus in $M$. gregarius would impact its diving abilities.
Furthermore, stem ziphiids share with their modern representatives the presence of an enlarged HF and the reduction of the bony lamina laterally limiting the HF (Bianucci et al., 1994, 2010; Lambert et al., 2013). This feature suggests that stem ziphiids were able to hear at great depth, just like modern ziphiids (Lambert et al., 2013). However, proportions of the HF were never quantified in Ziphiidae and compared to other odontocetes.

We have provided here a detailed description of some postcranial remains of the stem ziphiid Messapicetus gregarius from the late Miocene (Tortonian) of the southern coast of Peru (Bianucci et al., 2010, 2016b). Then, we have proposed a reconstruction of the musculature of the neck and forelimb for this species and compared it with extant odontocetes with a better-constrained foraging behaviour. Finally, we have quantified variation in the proportions of the forelimb and the HF in odontocetes to identify modifications related to deep-diving specialization.

\section{Material and methods}

\subsection{Specimen preparation}

The fossil specimens MUSM 2542 and 2548 were excavated and subsequently transported to the Museo de Historia Natural, Universidad Nacional Mayor de San Marcos, Lima (MUSM). They were prepared and consolidated by means of mechanical tools and standard fossil vertebrate preparation techniques by W. Aguirre under the scientific supervision of R. Varas-Malca in the Departamento de Paleontología de Vertebrados at MUSM.

\subsection{Institutional abbreviations}

1. IRSNB - Institut Royal des Sciences Naturelles de Belgique, Brussels, Belgium

2. MNHN - Muséum National d'Histoire Naturelle, Paris, France

3. MUSM - Museo de Historia Natural de la Universidad Nacional Mayor de San Marcos, Lima, Peru

4. MSNUP - Museo di Storia Naturale dell'Università di Pisa, Italy

5. NMNZ - National Museum of New Zealand Te Papa Tongarewa, Wellington, New Zealand

6. NRM - Naturhistoriska Riksmuseet, Stockholm, Sweden

7. SNM - Statens Naturhistoriske Museum, Copenhagen, Denmark

8. USNM - National Museum of Natural History, Smithsonian Institution, Washington, DC, USA 
Table 1. Set of linear measurements taken on the forelimb and skull of odontocetes.

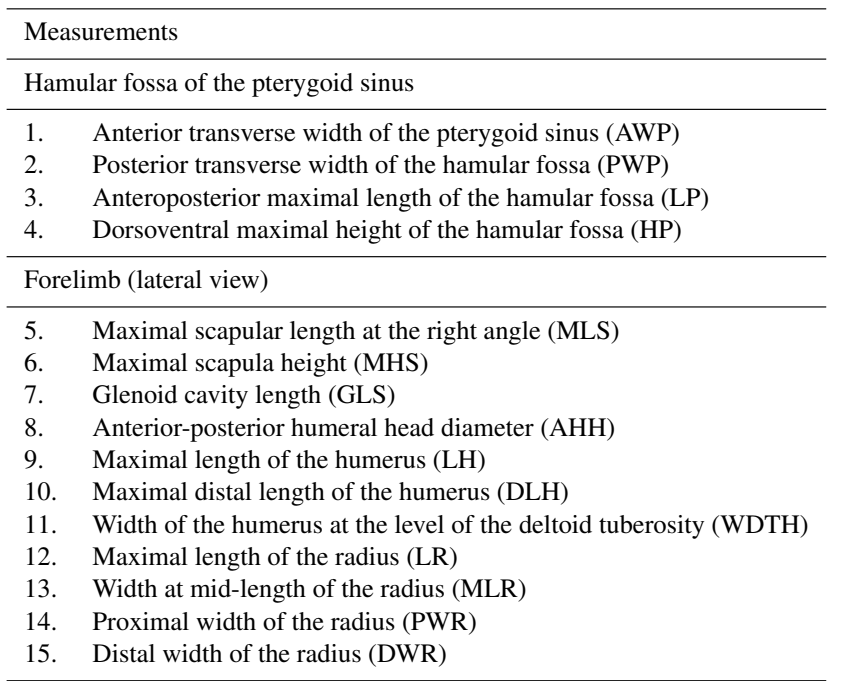

\subsection{Terminology}

The terminology used by Marx et al. (2016) and Fitzgerald (2016) was followed to describe the postcranial remains of Messapicetus gregarius. Muscle origins and insertions follow the nomenclature of the Standard Nomina Veterina Anatomica (International Committee on Veterinary Gross Anatomical Nomenclature, 2005). Muscle development was estimated using osteological markers found on postcranial remains of $M$. gregarius based on previous studies of cetacean myology (Benke, 1993; Cooper et al., 2007; Marx et al., 2016; Sanchez and Berta, 2010; Schulte, 1916; Uhen, 2004). These studies were used for the comparative work with the addition of direct observations from specimens of different institutions (see Dataset 1, (Ramassamy et al., 2018) for the complete list of specimens). The terminology used by Fraser and Purves (1960) was followed to discuss aspects of the pterygoid sinus morphology.

\subsection{Statistical analyses}

A set of 11 linear measurements for the forelimb and 4 linear measurements for the HF of odontocetes were selected with regard to the preserved parts of Messapicetus gregarius and directly measured with digital calipers $(0.1 \mathrm{~mm})$ to quantify the morphological variation (Table 1 and Fig. 1). Measurements of the HF and the forelimb were analysed separately. The dataset with HF measurements contained 48 specimens, while the dataset with forelimb measurements contained 46 specimens, each from 27 species (see Dataset 2, Ramassamy et al., 2018).
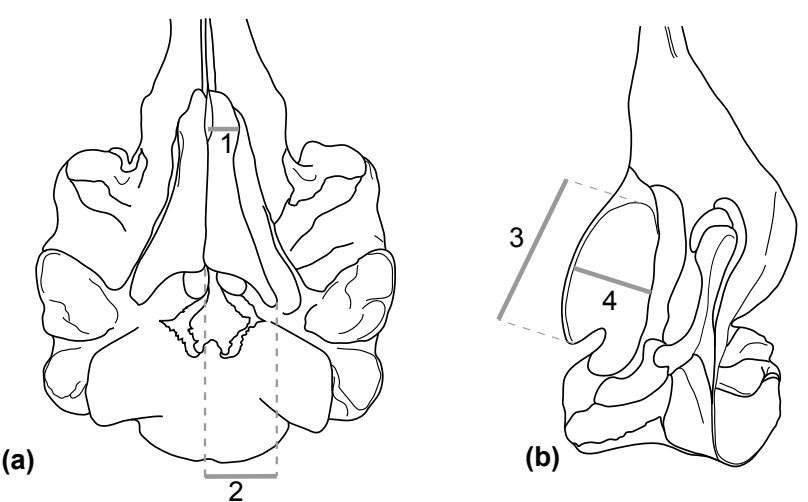

(c)
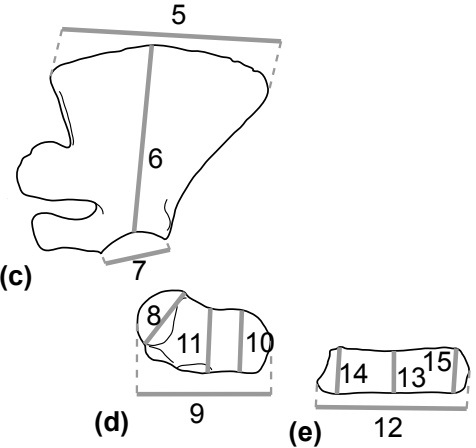

Figure 1. Set of linear measurements taken for the study exemplified in Hyperoodon ampullatus. (a) Skull in ventral view; (b) skull in lateral view; (c) scapula in lateral view; (d) humerus in lateral view; (e) radius in lateral view.

Two separate methods were applied to correct for intraspecific variation related to ontogenetic development. In the case of forelimb measurements, the method of the log-shape ratios was used (Mosimann, 1970). A variable "size" was computed as the geometric mean of all measurements of a particular structure for each individual. Each measurement for each specimen was then divided by the variable size. Finally, $\log$ transformation was performed on each divided measurement. The log-shape ratio procedure removes the effect of size, a variable that is interesting in the case of the HF. To keep the effect of size, raw measurements of the HF were analysed after applying a natural logarithmic transformation (Marcus, 1990). For each dataset, the median of the corrected values was computed for each sampled species and was used for the next analyses.

Phylogenetic comparative methods were required to evaluate the degree of association between deep-diving abilities and proportions of the forelimb and HF due to the disparity of odontocete species compared. Indeed, measurements from closely related species are statistically non-independent, thus precluding the use of statistical methods before correction (Felsenstein, 1985)

The topology of the subtree and divergence time used in this analysis were taken from the cetacean tree by McGowen et al. (2009), including all extant species sampled in this 
study. Up to now, no phylogenetic analysis includes the fossil species Messapicetus gregarius with all other extant odontocetes of our sample. Therefore, M. gregarius was simply added at the base of the ziphiid clade from McGowen et al. (2009). This relationship is supported by the most recent cladistic analyses including fossil Ziphiidae (Lambert et al., 2013; Bianucci et al., 2016a).

A phylogenetic principal component analysis (pPCA; Revell, 2009) was performed to visualize the results for the measurements of the forelimb and the HF of odontocetes with regard to their specialization for deep diving. The pPCA is an exploratory tool similar to the principal component analysis (PCA). The latter is used to reduce the dimensions of a multivariate set of observations, allowing for a discussion of the pattern of variation in the dataset. The original data are translated in a new coordinate system centred toward the mean of the different traits of the dataset and where the rotated axes correspond to the major axes of variation. The PCA conserves the variance and thus the distances between observations. Unlike a conventional PCA, the pPCA takes into account the topology of the tree by centring the dataset toward the estimated phenotype of the root node of the tree instead of the mean and by inversely weighting the covariance matrix by the phylogeny. Consequently, the major axes do not maximize variation, but represent the nonphylogenetic residual variation (Revell, 2009).

A Q-mode for phylogenetic regression method (D-PGLS) was used to control for the phylogenetic independence of the measurement residuals (Adams, 2014). A Brownian motion model of evolution was assumed. The D-PGLS is an extension of the phylogenetic generalized least squares (PGLS). The PGLS is a statistical method aiming at estimating the parameters of a linear regression between two variables while removing the effect of kinships (Martins and Hansen, 1997). The covariance due to the phylogeny is incorporated into the residual error, thus making them statistically independent. The main problem with the PGLS is that it can only accommodate one dependent variable, while our dataset contained multiple measurements. The D-PGLS is a distancebased method using a matrix of pairwise distances among specimens instead of the variance-covariance matrices used in the traditional PGLS (Adams, 2014). This method bears the advantage of accommodating multiple dependent variables, no matter the number of trait dimensions.

Multilinear linear models without phylogenetic correction were also performed using a multivariate analysis of variance (MANOVA) to see if the results differed from the D-PGLS.

While the measurements were the dependent variables, deep-diving specialization was chosen as the categorical explanatory variable. An arbitrary criterion was chosen to assess deep-diving species based on records of the deepest foraging dives for each species. Species were considered specialized deep divers when their deepest foraging dives recorded were $700 \mathrm{~m}$ or beyond. Deepest foraging dive depths for each species were collected from the literature (see Dataset 3, Ramassamy et al., 2018). Deepest foraging dives rather than mean foraging dives were selected for two reasons. First, quantitative data were not accessible for all species. Second, deepest foraging dives were assumed to better reflect maximal diving performances for each species, which would be limited by morphological or physiological factors, such as the HF size.

No depth records were found for Cephalorhynchus commersonii, Platanista gangetica, Sotalia fluviatilis, Mesoplodon bidens, M. bowdoini, and M. grayi. C. commersonii, $P$. gangetica, and $S$. fluviatilis were considered as nondeep divers because these species live in riverine systems or coastal waters (see Dataset 3, Ramassamy et al., 2018). Species of the genus Mesoplodon were all considered as deep divers based on $M$. densirostris, for which several diving records are known, and indirect evidence for other species (feeding areas and prey types; e.g., McLeod et al., 2003; Mead, 1989).

The extinct Messapicetus gregarius was not considered in the D-PGLS because its diving abilities are based on indirect evidence (Lambert et al., 2015). The basilosaurid Dorudon atrox was included in the analysis to evaluate whether the characteristics observed in Ziphiidae were a derived condition or symplesiomorphic. Averages from the measurements of the forelimb of D. atrox were taken from Uhen (2004). In agreement with the paleoenvironmental habits of $D$. atrox as reconstructed by Uhen (2004), this species was not considered as a deep diver in the present analysis.

All statistical analyses were performed with the software R 3.2.2 (R Development Core Team, 2015) with the packages car (Fox and Weisberg, 2011), geomorph (Adams and Otarola-Castillo, 2013), phytools (Revell, 2012), and caper (Orme, 2013). The script is available in Dataset 1 (Ramassamy et al., 2018).

\section{Systematic Paleontology}

\section{Order Cetacea Brisson, 1762}

Suborder Odontoceti Flower, 1867

Family Ziphiidae Gray, 1850

Genus Messapicetus Bianucci, Landini and Varola, 1992

Messapicetus gregarius Bianucci, Lambert and Post, 2011

\subsection{Referred material}

Specimen MUSM 2548: three cervical vertebrae including the axis, three thoracic and two thoracic-post-thoracic vertebrae all lacking the neural spine (Figs. 2-3), fused manubrium and left part of the second sternebra (Fig. 4), 11 complete to subcomplete ribs (Fig. 5); skull and mandibles are still in the field. Specimen MUSM 2542: partial right 
scapula lacking the acromion, the anterior part of the scapular blade, and the broken coracoid process (Fig. 6); partial left and right humeri (Fig. 7), complete left radius (Fig. 8); skull, mandibles, and other vertebrae of this individual are still in the field.

\subsection{Horizon and locality}

The specimens were discovered in the $200 \mathrm{~m}$ thick section of sediments from the Pisco Formation exposed at Cerro Colorado. They were identified under the fieldwork numbers $\mathrm{O} 37$ and $\mathrm{O} 39$ in the map provided by Bianucci et al. (2016b).

Two depositional sequences of the Pisco Formation, P1 and $\mathrm{P} 2$, are represented at Cerro Colorado and separated by an angular unconformity (Di Celma et al., 2016, 2017). The specimens MUSM 2542 and MUSM 2548 originate from the P1 sequence (the "lower allomember" of Di Celma et al., 2016), consisting of nearshore conglomerates and finegrained sandstones, bioturbated sandy siltstones, and mudstones (Di Celma et al., 2016). The lower allomember is rich in marine fossil vertebrates, such as cartilaginous and bony fish, marine turtles, crocodiles, sea turtles, sea birds, and seals (Bianucci et al., 2016b; Landini et al., 2017a, b; Parham and Pyenson, 2010; Stucchi et al., 2016). Cetaceans are represented by diverse taxa: Physeteroidea (Livyatan melvillei and aff. Acrophyseter sp.), Ziphiidae (M. gregarius, Chimuziphius coloradensis), Inioidea (Brachydelphis mazeasi and an undescribed taxon), two undescribed kentriodontid-like Delphinida, Balaenopteroidea, and $\mathrm{Ce}$ totheriidae (Bianucci et al., 2010, 2016b, c; Collareta et al., 2015; Gioncada et al., 2016; Lambert et al., 2010a). The geological age of the lower allomember is estimated as 9.98.9 Ma (Tortonian, Late Miocene) based on the presence of the diatom species Lithodesmium reynoldsii and radiometric dating of a local ash layer (Di Celma et al., 2016; Gariboldi et al., 2017). Diatom genera found in the lower and upper allomembers (e.g., Delphineis, Odontella, Rhaphoneis, Diplomenora) are typical of a neritic environment, whereas open-ocean diatoms species are less frequent (Di Celma et al., 2016; Gariboldi et al., 2017).

\subsection{Systematic attribution}

Both specimens were identified based on complete skulls and mandibles that were left on the field. They are attributed to the family Ziphiidae based on the enlargement of the hamular fossa of the pterygoid. In MUSM 2548, this is further confirmed by the presence of an enlarged apical alveolus on the mandible. The two skulls have an extremely elongated rostrum, representing approximately $75 \%$ of the total condylobasal length. Furthermore, MUSM 2548 displays the medial fusion of the premaxillae dorsal to the mesorostral groove along the rostrum. These two characteristics are typical of the genus Messapicetus.
The species $M$. gregarius is by far the most common ziphiid species in the lower allomember of Cerro Colorado, being represented by at least 13 specimens (Bianucci et al., $2016 b, c)$.

\section{Results}

\subsection{Description}

\subsubsection{Overview and ontogeny}

Both specimens are interpreted as adults based on the fully fused epiphyses of the vertebrae of MUSM 2548, the humeral head fused to the humeral shaft, and the epiphyseal ankylosis of each epiphysis of the radius in MUSM 2542. In the small odontocete Phocoena phocoena, extensive ankylosis of the postcranial skeleton characterizes adult specimens (Galatius and Kinze, 2003).

\subsubsection{Axial skeleton}

Axis. The subcomplete axis from specimen MUSM 2548 lacks the left lower transverse process, the left upper part of the neural canal, and the neural spine (Fig. 2a-c). The articulation facet with C3 is transversely wider than dorsoventrally high, with a height of $55 \mathrm{~mm}$ and a width of $76 \mathrm{~mm}$. The neural canal was originally oval, transversely wider than dorsoventrally high. The odontoid process is developed anteriorly, but not transversely widened, indicative of a small contact surface with the atlas. The well-developed lower transverse process $(75 \mathrm{~mm})$ is oriented lateroventrally. Its posterior surface is excavated along most of its surface. Two fossae medially separated by the hypapophysis excavate the ventral surface of the centrum of the axis.

Other cervical vertebrae. The two other preserved cervical vertebrae from specimen MUSM 2548 are subcomplete and identified as putative C5-C6 (Fig. 2d-f) and C7 (Fig. 2g-i).

One cervical vertebra is referred to as C5 or C6 based on the presence of a vertebrarterial canal extended along the whole dorsoventral height of the centrum, the presence of a lower transverse process measuring $29 \mathrm{~mm}$ transversely, and the anterior and posterior articular facets dorsoventrally smaller than transversely wide. These features were observed in C5 and C6 of several extant ziphiid species (Berardius arnuxii, Mesoplodon bidens, M. bowdoini, M. densirostris, and M. grayi; see Dataset 1 (Ramassamy et al., 2018) for the institution numbers). The neural canal shape is estimated as pentagonal based on the preserved part of the dorsolaterally directed left pedicle (Fig. 2d). The other cervical vertebra is identified as $\mathrm{C} 7$ based on the centrum being more dorsoventrally compressed than in C5-C6 and the presence of a fovea for the first rib capitulum on the lateral surface of the vertebra. Lower transverse processes are absent along the vertebra centrum. 

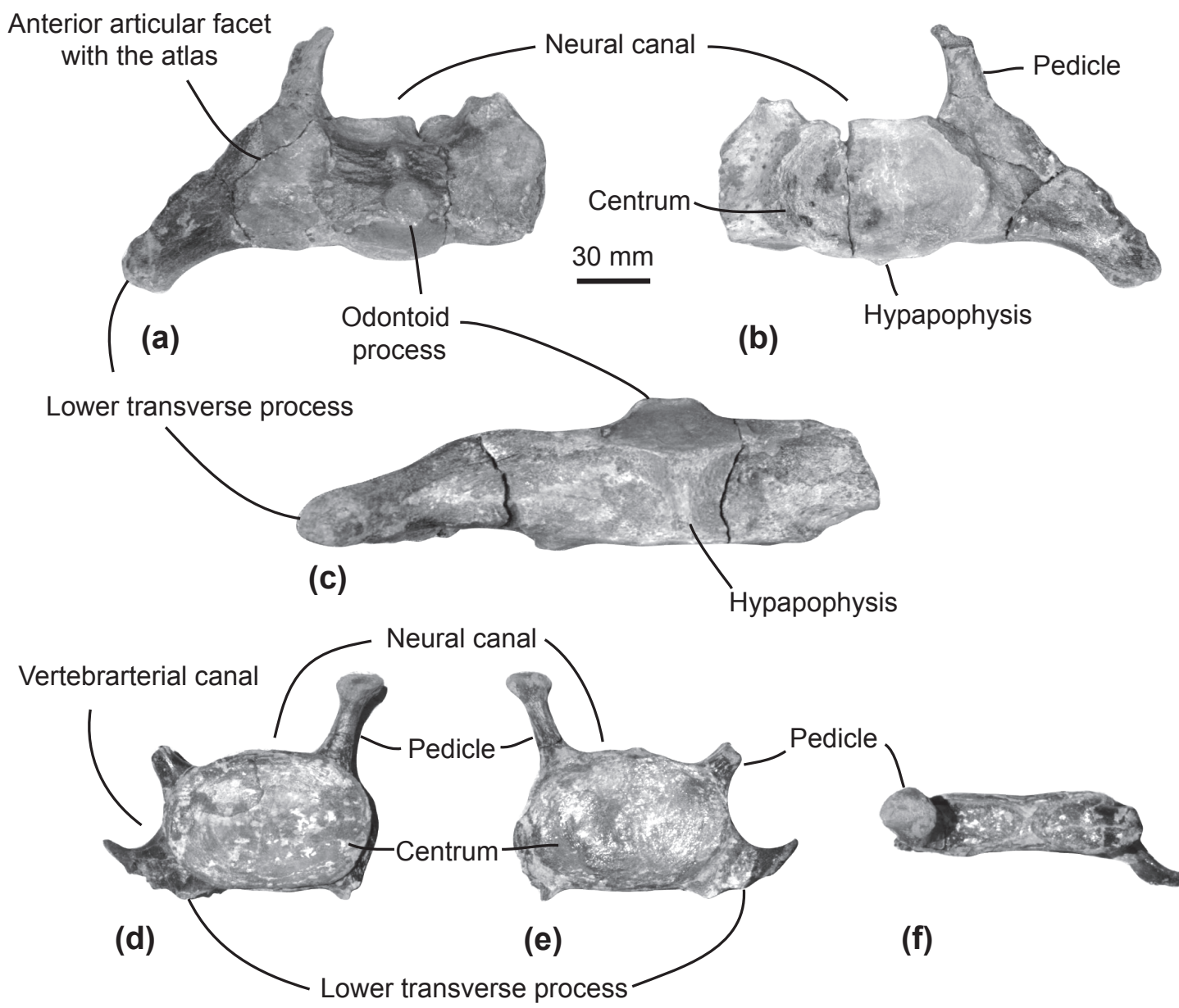

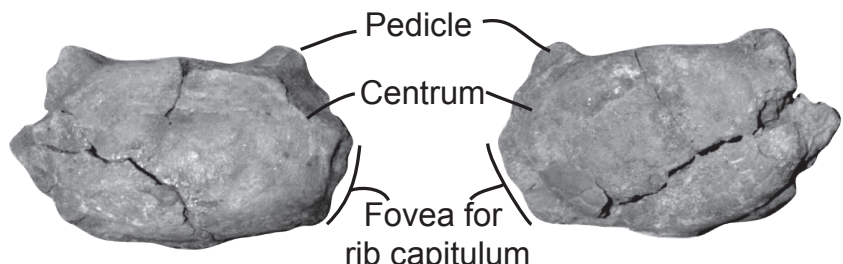

(g) (h)

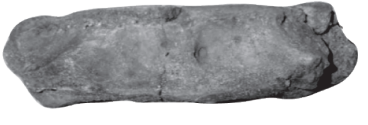

(i)

Figure 2. Cervical vertebrae of the specimen MUSM 2548, Messapicetus gregarius. Axis in anterior (a), posterior (b), and ventral view (c); C5-C6 in anterior (d), posterior (e), and dorsal view (f); C7 in anterior (g), posterior (h), and dorsal view (i).

Thoracic-post-thoracic vertebrae. The specimen MUSM 2548 is represented by three thoracic and two thoracic-postthoracic vertebrae (Fig. 3). Their precise position along the vertebral column cannot be identified in the absence of the complete series. Consequently, a relative position is given here in an anteroposterior sequence from $\mathrm{A}$ to $\mathrm{E}$.

All thoracic and post-thoracic vertebrae possess a centrum transversely wider than dorsoventrally high (Table 2) and oval in shape. An exception to this pattern is the anterior epiphysis of vertebra A, which is dorsoventrally higher than transversely wide and more rectangular (Fig. 3a). Vertebrae $\mathrm{A}, \mathrm{B}$, and $\mathrm{G}$ are identified as thoracics because of the presence of a fovea for the rib tuberculum on the upper transverse process and a fovea for the rib capitulum along their centrum (Fig. 3a-b and 3d). In posterior view of vertebrae A, B, and $\mathrm{G}$, the fovea for the rib capitulum is located along the dorsolateral surface of the centrum. The extent of this fovea suggests these to be posterior to the thoracic vertebra 1. Indeed, in all extant Ziphiidae examined, the fovea extends along the whole lateral surface of the centrum. 

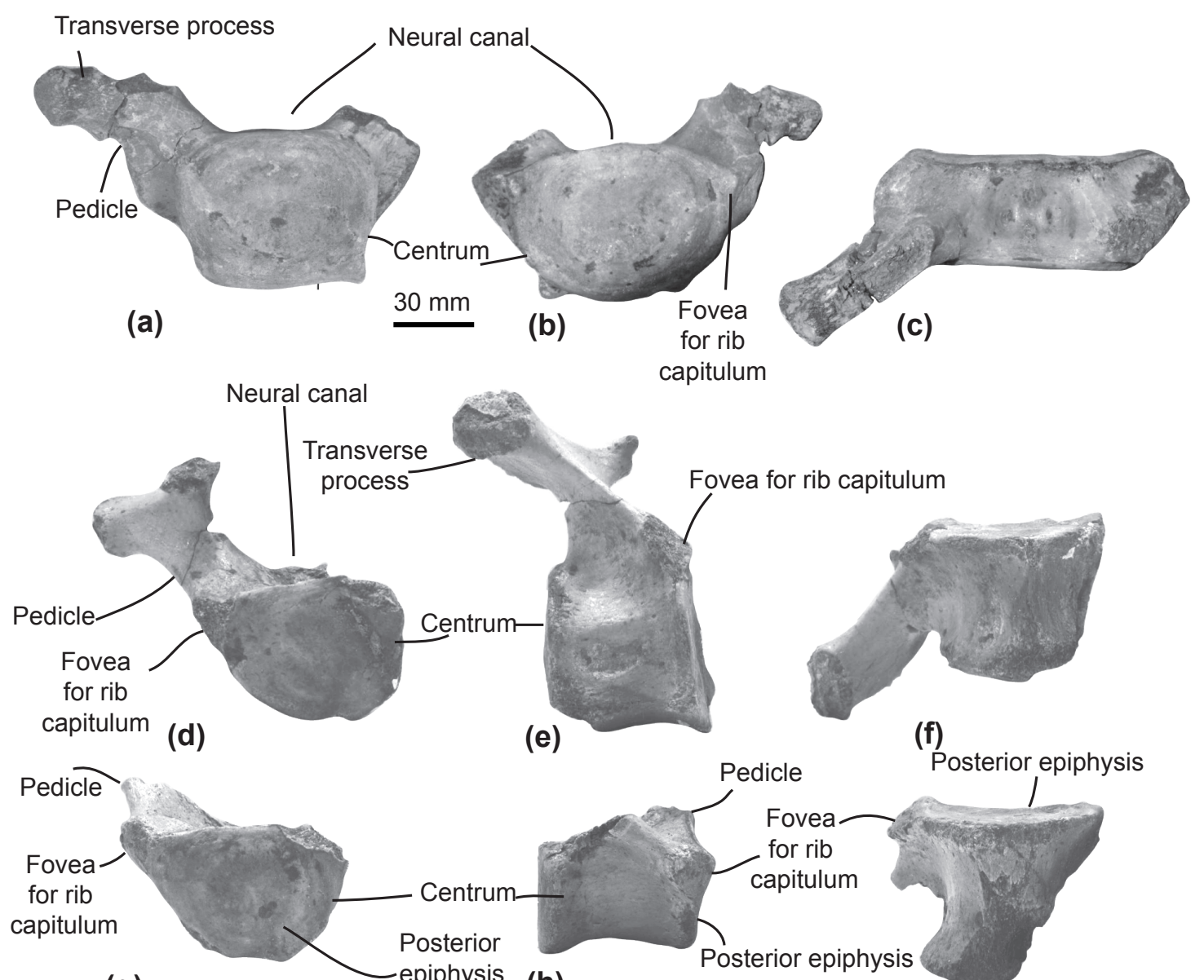

(g)

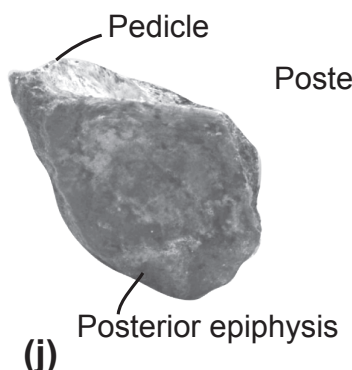

(j) (h)

epiphysis

Posterior epiphysis

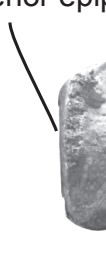

Figure 3. Thoracic and post-thoracic vertebrae of the specimen MUSM 2548, Messapicetus gregarius. Thoracic vertebra A in anterior (a), posterior (b), and dorsal view (c); thoracic B in posterior (d), left lateral (e), and ventral view (f); thoracic C in posterior (g), lateral (h), and ventral view (i); thoracic-post-thoracic D in posterior (j) and lateral view (k); thoracic-post-thoracic E in lateral view (l).

\subsubsection{Sternum and ribs}

Sternum. Two elements of the sternum are preserved in the specimen MUSM 2548: the complete manubrium and the left half of the sternebra 2 (Fig. 4). The two elements are unfused to each other. The manubrium is roughly $\mathrm{H}$-shaped, its anterior margin being marked by a jugular notch. This bone is transversely wider (at least $220 \mathrm{~mm}$ ) than antero- posteriorly long $(193 \mathrm{~mm})$. In anterior view, it is ventrally convex (Fig. 4b). Its lateral margin is concave, progressively narrowing posteriorly. A medial notch is present posteriorly, longer anteroposteriorly than transversely wide. The two posteriormost margins of the manubrium are less transversely widened than the anteriormost margins. An articular facet for the first rib is present anterolaterally. The shape of the preserved left element of sternebra 2 is similar to the left 


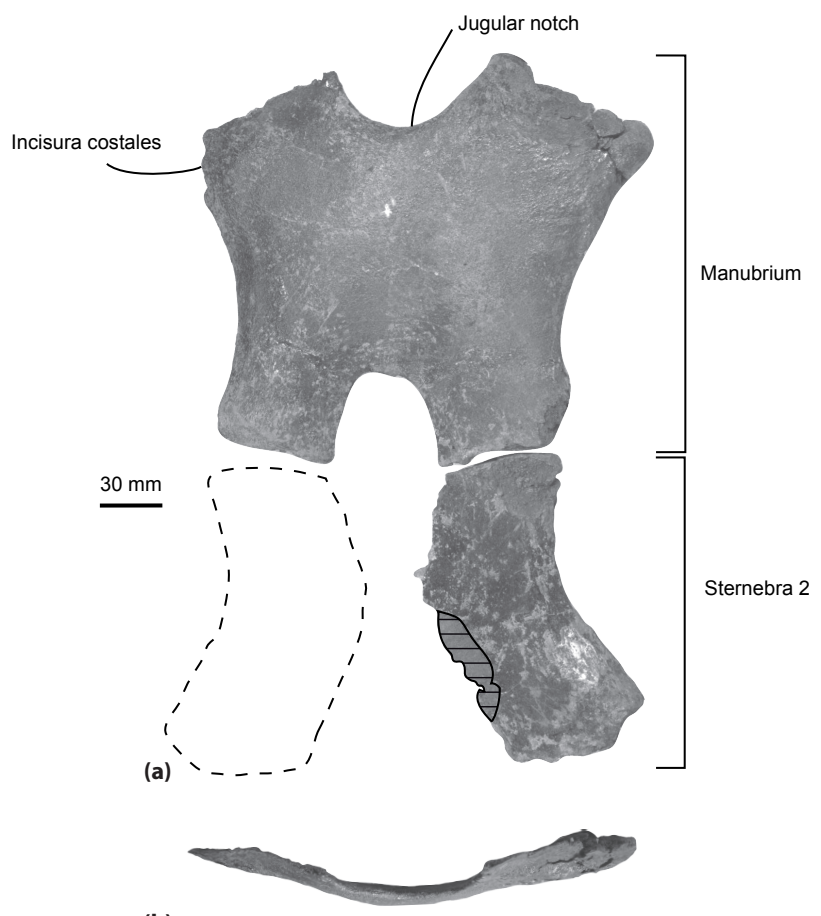

(b)

Figure 4. Sternum of the specimen MUSM 2548, Messapicetus gregarius, in ventral view (a) and manubrium element in anterior view (b). Horizontal solid lines indicate major break. The dashed line represents a reconstruction of the second element of the sternebra 2.

half of the manubrium, except for the deeper excavation of its lateral margin.

Ribs. Among the 12 partial ribs recovered in specimen MUSM 2548 (Fig. 5), four pairs are tentatively positioned based on respective head shape (Fig. 5a-h) and by comparison with the identified ribs of Ninoziphius platyrostris (de Muizon, 1984). The first pair (Fig. 5a-b) is the shortest. Compared to the other ribs, it possesses the shortest neck, the widest and flattest body, and the thickest angle. The following pairs until pair 4 are progressively longer, thinner, and less flattened, with a longer neck and a shorter capitulum. At least the four first pairs are double-headed. The distal part of each rib is flattened and exhibits longitudinal striations, most likely where muscles inserted.

\subsubsection{Forelimb}

Scapula. The fan-shaped partial right scapula of MUSM 2542 is marked by multiple fractures. Some pieces were displaced, thus slightly affecting its original shape (Fig. 6). In ventral view, the glenoid cavity is oval and more elongated anteroposteriorly than transversely wide. Posterodorsally to the glenoid fossa, the base of the coracoid process is too damaged to allow for a reconstruction. In lateral view, on the posterior surface of the scapula, a crest separating the infraspinous fossa from the teres fossa is salient dorsoventrally.
Humerus. The two humeri of the specimen MUSM 2542 are partially preserved. Since the left humerus lacks the humeral head and is less well preserved (Fig. 7e-i), only the right humerus is described here (Fig. 7a-d).

The shaft of the right humerus is broken at mid-length, slightly displacing dorsally the distal articulation with the radius and the ulna (Fig. 7a-d). The humeral head is hemispherical and separated from the great tuberosity by a neck visible in ulnar and radial view (Fig. 7c-d). In lateral view, the head of the humerus represents one-third of the total length of the humerus (Fig. 7b). In medial view, the surface of the great tuberosity is flattened, approximately reaching the same proximal level as the head of the humerus. In lateral view, a deltoid ridge is developed along the anterior margin of the humerus at approximately mid-length of the humerus.

In distal view, the articular facets for the radius and the ulna are separated by the distal crest. In lateral view, each articular facet occupies approximately half of the distal surface of the humerus.

Radius. The left radius of MUSM 2542 is complete (Fig. $7 \mathrm{j}-1$ ). It curves proximodistally and slightly transversely. The facet for articulation of the humerus is oriented anteroproximally. Distally, the articulations for the scaphoid and the lunate can be differentiated based on their orientation (Fig. 7j-k). Each occupies approximately half of the distal anteroposterior width of the radius. The articulation for the scaphoid appears straight in lateral view, distally facing, while the articulation for the lunate is more oblique, posterodistally facing.

\subsection{Muscle reconstruction of $M$. gregarius and comparisons with other ziphiid species}

\subsubsection{Neck muscles}

M. longus colli. In extant cetaceans, this muscle originates from the lower transverse process of C6 (Schulte, 1916; Uhen, 2004). It inserts into the ventral surface of the axis centrum. The M. longus colli flexes the neck. The origin of the $\mathrm{M}$. longus colli could not be reconstructed here because of the uncertainty of the putative C5-C6 identification. In Messapicetus gregarius, right and left muscles inserted into the ventral excavations of the axis centrum separated by the hypapophysis (Fig. 8a).

The axis of Ninoziphius platyrostris displays ventral excavations for the M. longus colli similar to M. gregarius. Furthermore, de Muizon (1984) interpreted the presence of a ventral tubercle located on the atlas as another region of insertion for the $\mathrm{M}$. longus colli. The $\mathrm{M}$. longus colli most likely originated from the lower transverse process of C6 of $N$. platyrostris, even though we could not identify the precise area. Transversely, the preserved lower process of C6 in $N$. platyrostris measured $20 \mathrm{~mm}$ long. It was similar in size and shape to the lower transverse process of the putative C5-C6 of MUSM 2548. 


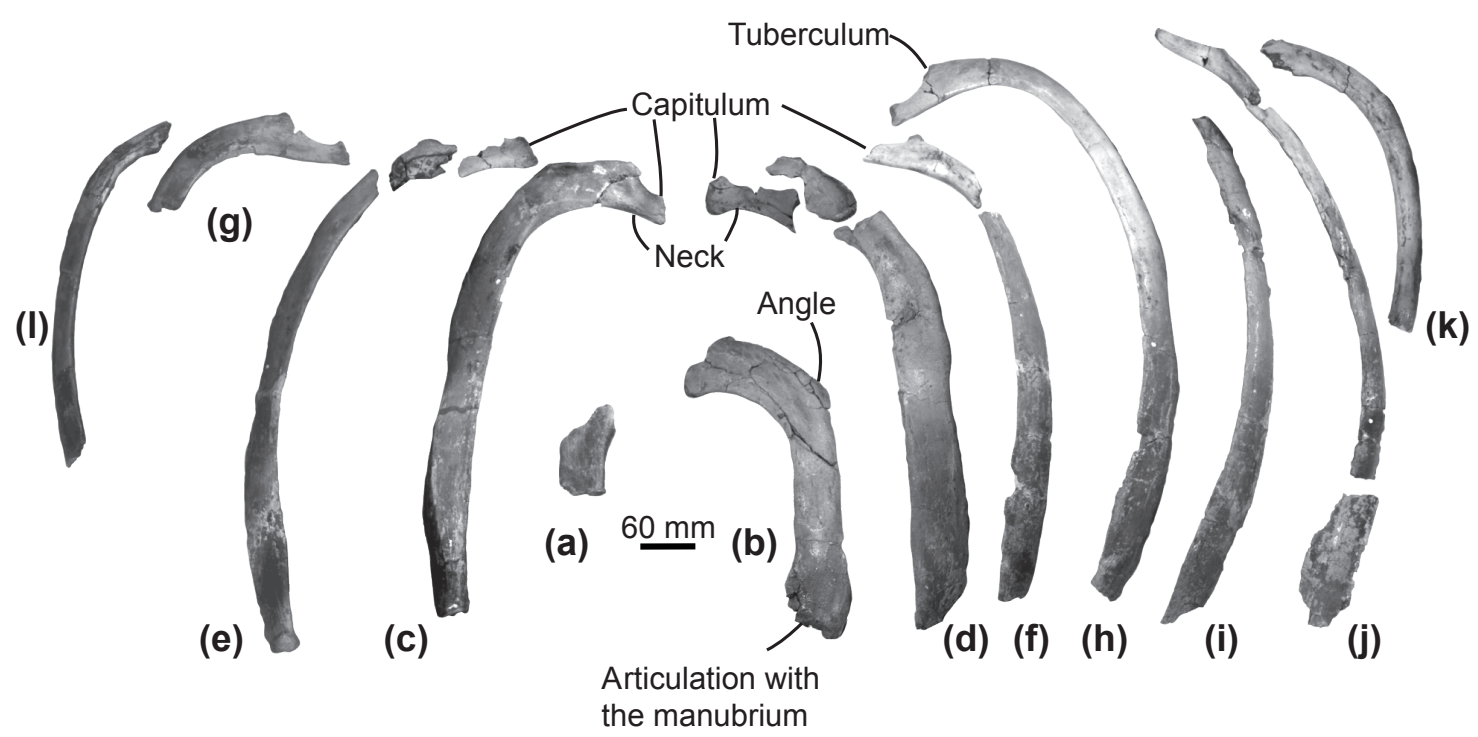

Figure 5. Ribs of the specimen MUSM 2548, Messapicetus gregarius, in anterior view. Pair 1 (a) and (b); pair 2 (c) and (d); pair 3 (e) and (f); pair 4 (g) and (h); (i), (j), (k), and (l) cannot be precisely positioned.

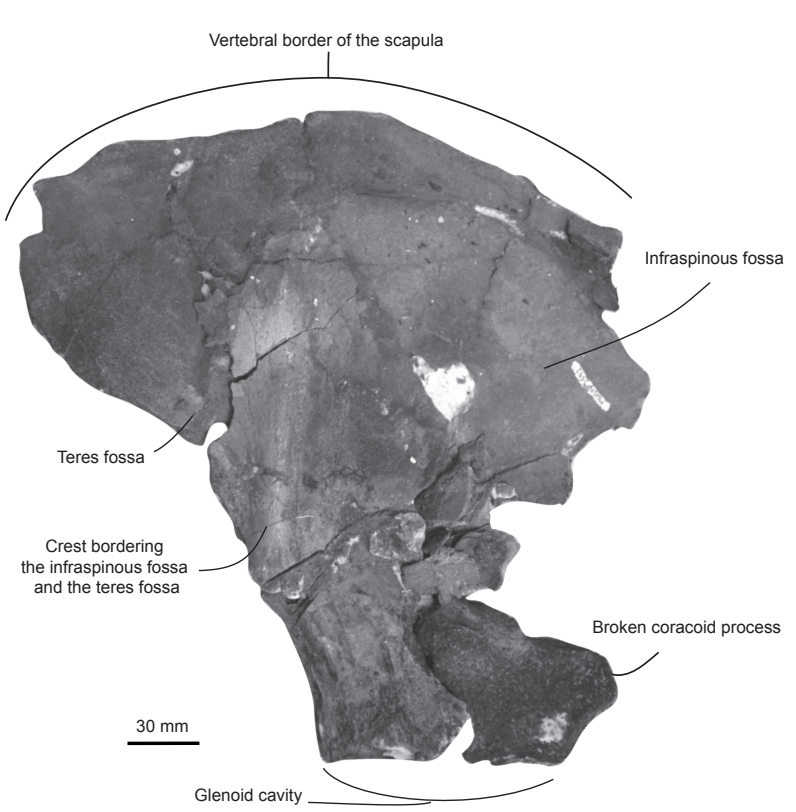

Figure 6. Right scapula of the specimen MUSM 2542, Messapicetus gregarius, in dorsal view.

Heavily abraded posteroventrally, the partial atlas of the middle Miocene Berardiinae Archaeoziphius microglenoideus probably had a poorly developed (if any) ventral tubercle (Lambert and Louwye, 2006). This suggests a reduction of the $\mathrm{M}$. longus colli insertion area as compared to $N$. platyrostris. The atlas of the late Miocene crown ziphiid Nazcacetus urbinai lacks a ventral tubercle (Lambert et al., 2009); the absence of ventral excavations in the axis of the latter further indicates reduced insertions for the M. longus colli as compared to M. gregarius and $N$. platyrostris. Furthermore, the lower transverse process of C6 in the holotype of $N$. urbinai is as long transversely as the process of other posterior cervicals, thus indicating a reduced origin area for the $\mathrm{M}$. longus colli. Osteological markers for insertion areas of the M. longus colli into the atlas and the axis were generally more reduced in the observed extant ziphiids as compared to $M$. gregarius and $N$. platyrostris (Table 2); the axis consistently lacks deep ventral excavations for the M. longus colli in contrast to M. gregarius and N. platyrostris (Fig. 8).

A ventral tubercle is rarely present on the atlas of extant ziphiids, except in Mesoplodon grayi and Berardius spp. (Dataset 1, Ramassamy et al., 2018). In addition, the lower transverse process of $\mathrm{C} 6$ is more developed in Mesoplodon bidens, $M$. densirostris, and $M$. grayi than in $N$. platyrostris and other crown ziphiids observed (Fig. 9d-e). This feature indicates a relatively larger origin area for the $\mathrm{M}$. longus colli in these three Mesoplodon species.

Mm. intertransversarii ventrales cervicis. This muscle also originates from the lower transverse process of C6 (de Muizon, 1984; Schulte, 1916; Uhen, 2004). It bears multiple insertions into the posterior side of the transverse processes of the atlas, axis, $\mathrm{C} 3$, and $\mathrm{C} 4$. It participates in the lateral flexion of the neck. On the posterior side of the unfused axis of Messapicetus gregarius MUSM 2548, the presence of a large depression along the lower transverse process suggests a large area of insertion for the $\mathrm{Mm}$. intertransversarii ventrales cervicis (Fig. 8b).

Similar insertion areas are observed in $N$. platyrostris (Fig. 8d). As for the M. longus colli, the Mm. intertransver- 


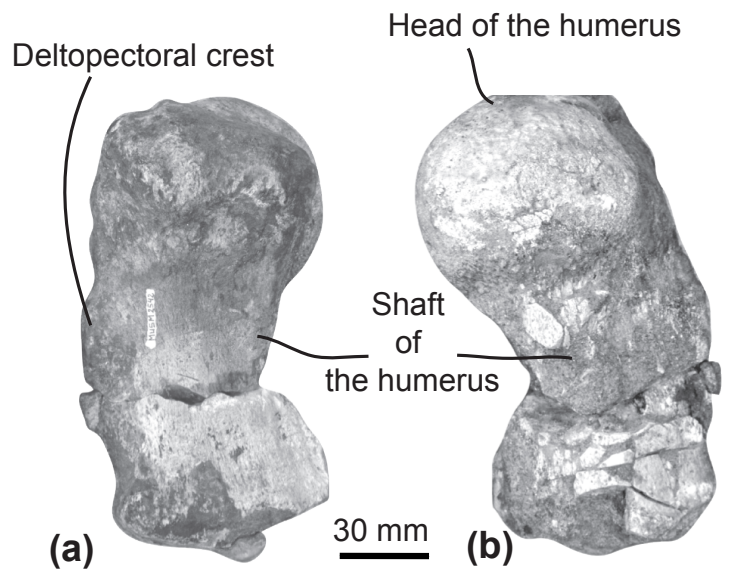

(e)

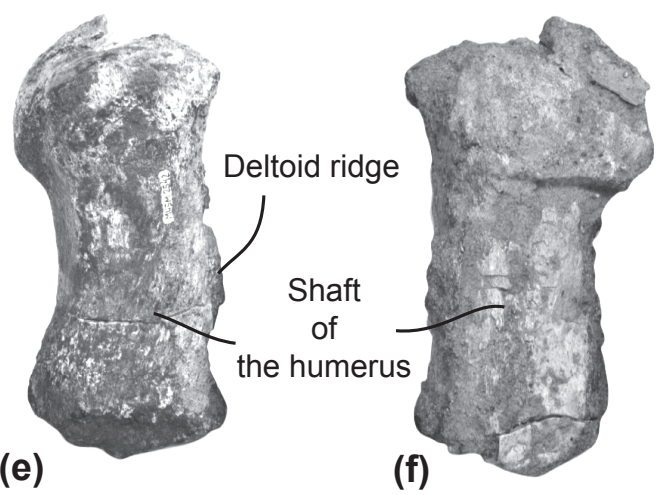

Great tuberosity $\longrightarrow$ Head
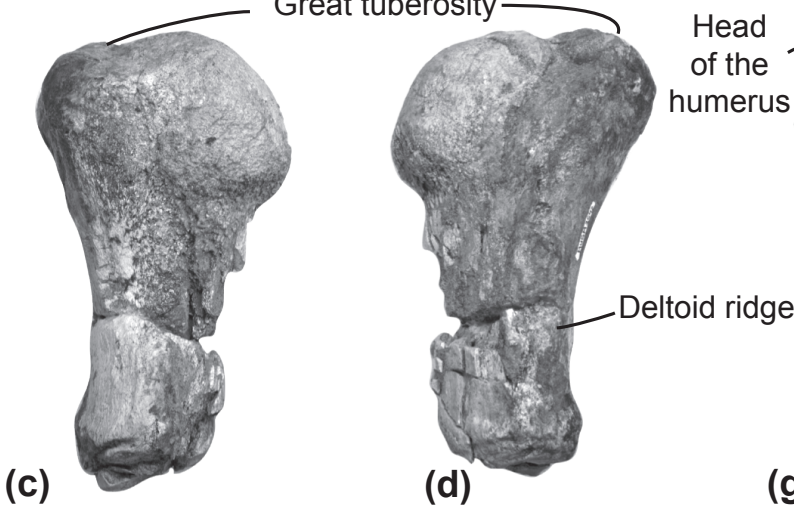

(d)

(g)

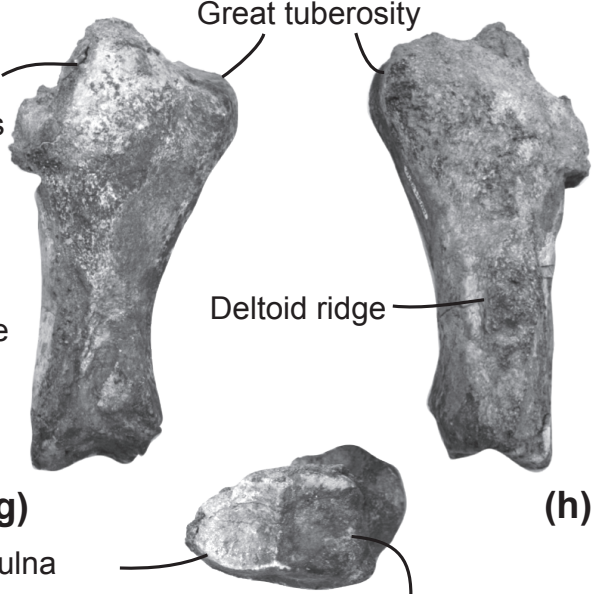

Articulation with the ulna

(h)

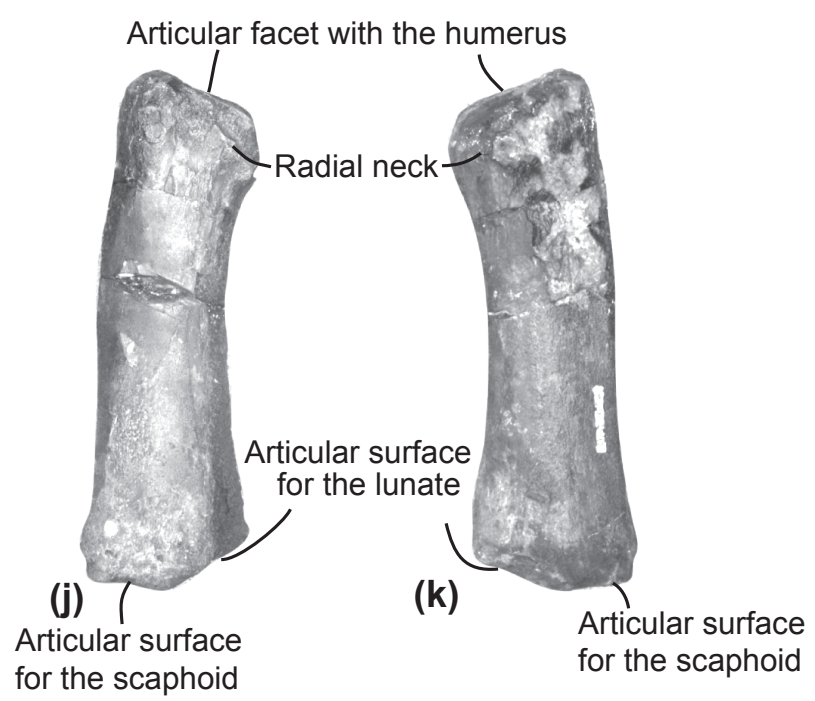

(i) Articulation

with the radius

(I)

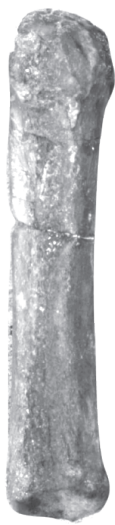

Figure 7. Humeri and left radius of MUSM 2542, Messapicetus gregarius. Right humerus in medial (a), lateral (b), ulnar (c), and radial view (d); left humerus in medial (e), lateral (f), ulnar (g), radial (h), and posterior view (i); left radius in lateral (j), medial (k), and ulnar view (l). 
Table 2. Measurements of the vertebrae from specimen MUSM 2548, Messapicetus gregarius. Thoracic-post-thoracic vertebrae from A to E are ordered in relative position; e stands for estimated measurements, and "-_" indicates missing measurements.

\begin{tabular}{lrrrrrrrr}
\hline Feature & Axis & C5-C6 & C7 & A & B & C & D & E \\
\hline Transverse width at the level of transverse processes & $186 \mathrm{e}$ & - & - & $162 \mathrm{e}$ & $184 \mathrm{e}$ & - & - & - \\
Anterior transverse width centrum & - & 73 & 75 & 69 & $70 \mathrm{e}$ & 71 & $54 \mathrm{e}$ & - \\
anterior transverse height centrum & - & 74 & 76 & 75 & 53 & 52 & 55 & - \\
Posterior transverse height centrum & 55 & 56 & 57 & 54 & - & - & - & - \\
Posterior transverse width centrum & 76 & 57 & 59 & 55 & - & - & - & - \\
Anteroposterior thickness centrum & 12 & 21 & 28 & 37 & 52 & 63 & 72 & 82 \\
Transverse width neural canal & 51 & - & - & - & - & - & - & - \\
\hline
\end{tabular}

Table 3. Summary of the main features relative to neck musculature in extant and fossil Ziphiidae. All specimens were directly consulted.

\begin{tabular}{|c|c|c|c|c|c|}
\hline Species & Sample & $\begin{array}{l}\text { Number of fused } \\
\text { cervical vertebrae }\end{array}$ & $\begin{array}{l}\text { Ventral tubercle on } \\
\text { the atlas }\end{array}$ & $\begin{array}{l}\text { Ventral excavations } \\
\text { on the axis }\end{array}$ & $\begin{array}{l}\text { Development of the } \\
\text { lower transverse } \\
\text { process of C6 }\end{array}$ \\
\hline $\begin{array}{l}\text { Messapicetus } \\
\text { gregarius }\end{array}$ & 1 & 0 & $?$ & present & $?$ \\
\hline $\begin{array}{l}\text { Ninoziphius } \\
\text { platyrostris }\end{array}$ & 1 & 2 & present & present & reduced \\
\hline $\begin{array}{l}\text { Archeoziphius } \\
\text { microglenoideus }\end{array}$ & 1 & $?$ & absent & $?$ & $?$ \\
\hline $\begin{array}{l}\text { Nazcacetus } \\
\text { urbinai }\end{array}$ & 1 & 2 & absent & absent & reduced \\
\hline Berardius sp. & 2 & 3 & present & absent & reduced \\
\hline $\begin{array}{l}\text { Hyperoodon } \\
\text { ampullatus }\end{array}$ & 11 & 7 & absent & absent & absent \\
\hline $\begin{array}{l}\text { Mesoplodon } \\
\text { bidens }\end{array}$ & 2 & 3 & absent & absent & $\begin{array}{l}\text { more developed than in } \\
\text { the other cervicals }\end{array}$ \\
\hline $\begin{array}{l}\text { Mesoplodon } \\
\text { bowdoini }\end{array}$ & 1 & 3 & absent & absent & reduced \\
\hline $\begin{array}{l}\text { Mesoplodon } \\
\text { densirostris }\end{array}$ & 2 & 3 to 5 & absent & absent & $\begin{array}{l}\text { more developed than in } \\
\text { the other cervicals }\end{array}$ \\
\hline $\begin{array}{l}\text { Mesoplodon } \\
\text { grayi }\end{array}$ & 1 & 2 & present & absent & $\begin{array}{l}\text { more developed than in } \\
\text { the other cervicals }\end{array}$ \\
\hline $\begin{array}{l}\text { Tasmacetus } \\
\text { shepherdi }\end{array}$ & 3 & 5 to 6 & absent & absent & reduced \\
\hline $\begin{array}{l}\text { Ziphius } \\
\text { cavirostris }\end{array}$ & 4 & 4 to 5 & absent & absent & reduced \\
\hline
\end{tabular}

sarii ventrales cervicis likely originated from the lower transverse process of C6, even though the precise areas cannot be identified. Unlike $M$. gregarius, the atlas and axis were fused in $N$. platyrostris, considerably reducing lateral flexibility in the anterior neck region.

In Nazcacetus urbinai (Lambert et al., 2009), the lower transverse process of the axis is not as enlarged as in M. gre- garius MUSM 2548, and the cervical vertebrae 3 to 7 are free, while the atlas and axis are fused.

Conversely, many extant Ziphiidae display extensive fusion of the neck vertebrae; none of the species with data available bear a free axis at the adult stage (Lambert et al., 2015). For example, in Hyperoodon ampullatus all cervical vertebrae are consistently fused in both males and females (Fig. 9c). With regard to the lower transverse process of C6, 
as for the M. longus colli, an accurate origin of the Mm. intertransversarii cervicis could not be identified in extant ziphiids.

M. rectus capitis dorsalis major. This muscle originates from the neural spine of the axis and inserts into the nuchal crest of the supraoccipital bone (Schulte, 1916; Uhen, 2004). It extends and stabilizes the head.

Even though the neural spine of the axis is not preserved in M. gregarius MUSM 2548, a comparison between the stem ziphiid N. platyrostris and crown ziphiids is relevant. The subcomplete neural spine of the holotype of $N$. platyrostris was assessed by de Muizon (1984) to be longer and thinner than in extant ziphiids, except Hyperoodon ampullatus (Fig. 9). The condition of the neural spine in extant ziphiids from our dataset confirms this statement, except in the case of Tasmacetus shepherdi, for which the proportionally longer neural spine was closer to $N$. platyrostris than to other extant Ziphiidae. In Nazcacetus urbinai, the neural spine of the axis is strongly reduced compared to $N$. platyrostris, suggesting a smaller origin area for the $\mathrm{M}$. rectus capitis dorsalis major.

\subsubsection{Forelimb muscles}

$M$. supraspinatus. The M. supraspinatus originates from the scapula, in the supraspinous fossa, and along the medial side of the acromion (Benke, 1993; Marx et al., 2016). It inserts into the great tuberosity of the humerus. The main action of the M. supraspinatus is to abduct the humerus.

Even though the bad preservation of the region around the supraspinatus fossa and the acromion in $M$. gregarius MUSM 2542 precludes a reconstruction of the origin of this muscle, the flattened and individualized great tuberosity of the humerus observed in MUSM 2542 suggests this muscle to be as developed as in extant Ziphiidae. Indeed, we observed an individualized great tuberosity in Berardius spp., Hyperoodon spp., Indopacetus pacificus, Mesoplodon bidens, M. bowdoini, M. densirostris, M. grayi, Tasmacetus shepherdi, and Ziphius cavirostris. A flattened great tuberosity was also present in the isolated humerus MNHN SAS 943, tentatively attributed to Ninoziphius platyrostris by de Muizon (1984).

M. deltoideus. The M. deltoideus originates from the infraspinous fossa, the spine of the scapula, and part of the acromion. It inserts into the lateral side of the anterior edge of the deltoid ridge of the humerus. Its main action is to extend the humerus, while the acromial fibres are involved in the abduction of the latter (Marx et al., 2016; Benke, 1993). We could not accurately assess the origin area of the M. deltoideus based on the partial scapula of M. gregarius MUSM 2542. Nevertheless, the presence of a deltoid ridge along the anterior surface of the humerus indicates a moderate development of this muscle as compared to Physeteroidea that display a deltoid ridge more developed proximodistally (Benke, 1993). A developed deltoid ridge is also present in MNHN
SAS 943 Ninoziphius platyrostris and in all the extant ziphiids examined in this study.

$M$. infraspinatus. The M. infraspinatus originates from the posterior surface of the scapula, posterior to the M. deltoideus (Benke, 1993; Marx et al., 2016). It inserts into a small fossa distal to the head of the humerus. This muscle acts as an extensor of the humerus and slightly participates in its adduction (Benke, 1993). The posterior crest along the lateral surface of the scapula of Messapicetus gregarius MUSM 2542 defines posteriorly the origin of the M. infraspinatus. This crest is similarly developed as in a fragmentary scapula of MSNUP 115760 partial skeleton of Messapicetus longirostris described by Bianucci et al. (2016a). However, the eroded surface of the two humeri of M. gregarius MUSM 2542 precluded us from assessing its insertion area. In the isolated humerus MNHN SAS 943, tentatively associated with Ninoziphius platyrostris by de Muizon (1984), we note the presence of a fossa distal to the head of the humerus where the M. infraspinatus most likely inserted. We observe a similar fossa in Berardius spp., Hyperoodon spp., Indopacetus pacificus, Mesoplodon bidens, M. bowdoini, M. densirostris, M. grayi, Tasmacetus shepherdi, and Ziphius cavirostris.

$M$. teres major. The M. teres major originates from the posterior region of the scapula in the teres fossa (Benke, 1993; Marx et al., 2016). It inserts into the posteroproximal part of the humerus. This muscle adducts the humerus and allows its inward rotation. The posterior crest in the scapula of Messapicetus gregarius MUSM 2542, M. longirostris MSNUP 115670, and all extant ziphiids of the sample defines anteriorly the origin area of the $\mathrm{M}$. teres major.

\subsection{Statistical results}

\subsubsection{Hamular fossa of the pterygoid sinus}

The relationship between HF proportions and deep-diving abilities was revealed as significant with and without phylogenetic correction (with phylogenetic correction: $F$ ratio $=12.504 ; p$ value $=0.001$; without phylogenetic correction: $F$ ratio $=18.078 ; p$ value $\left.=2.82 \times 10^{-6}\right)$. The four linear measurements taken were sufficient to distinguish ziphiid species from other odontocetes of the sample, particularly when the principal components (PCs) 1 and 2 were combined (Fig. 11). All ziphiids were characterized by an enlarged HF both anteroposteriorly and dorsoventrally as compared to other odontocetes (Fig. 11). The deep-diving species Grampus griseus and Physeter macrocephalus showed the same tendency as observed in ziphiid species. The species Globicephala melas, Monodon monoceros, and Pseudorca crassidens also possessed an anteroposteriorly and dorsoventrally enlarged HF, but could be distinguished from Ziphiidae based on their anteriorly wider HF. Messapicetus gregarius exhibited an enlarged HF similar to other Ziphiidae. However, M. gregarius could be differentiated from other ziphiids 
(a)

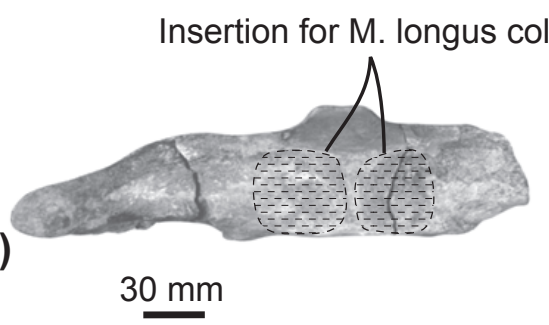

Insertion for $\mathrm{M}$. longus colli on axis

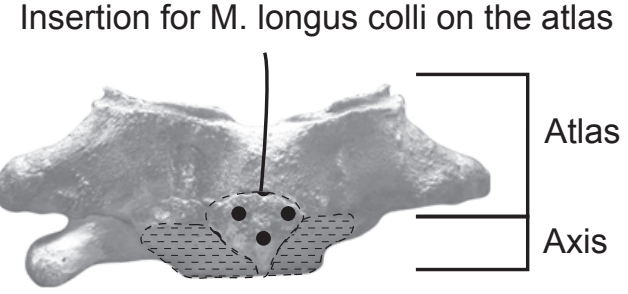

(c)

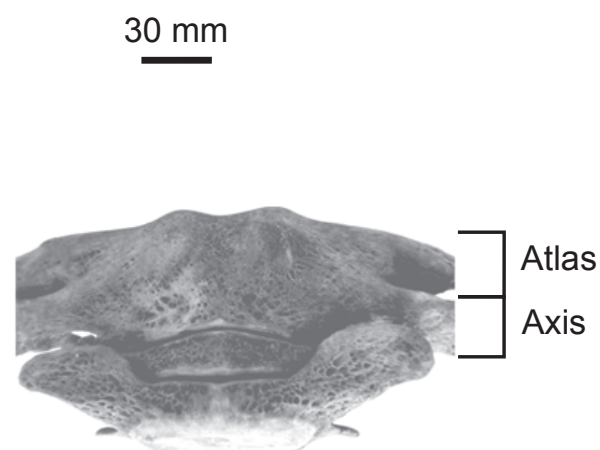

(e)

(e) $\quad 30 \mathrm{~mm}$

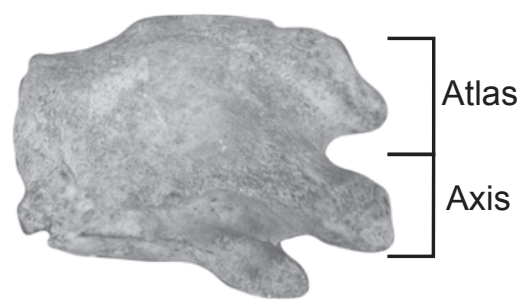

$30 \mathrm{~mm}$ (b)

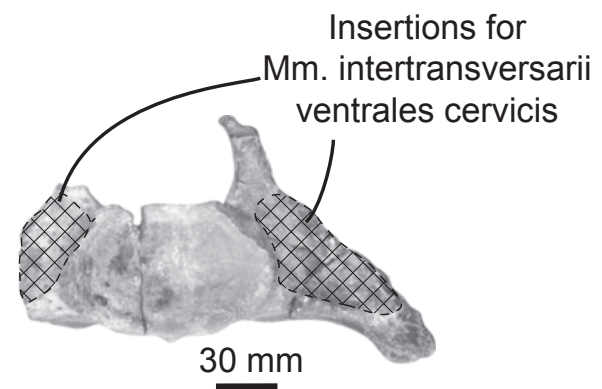

(d) $30 \mathrm{~mm}$
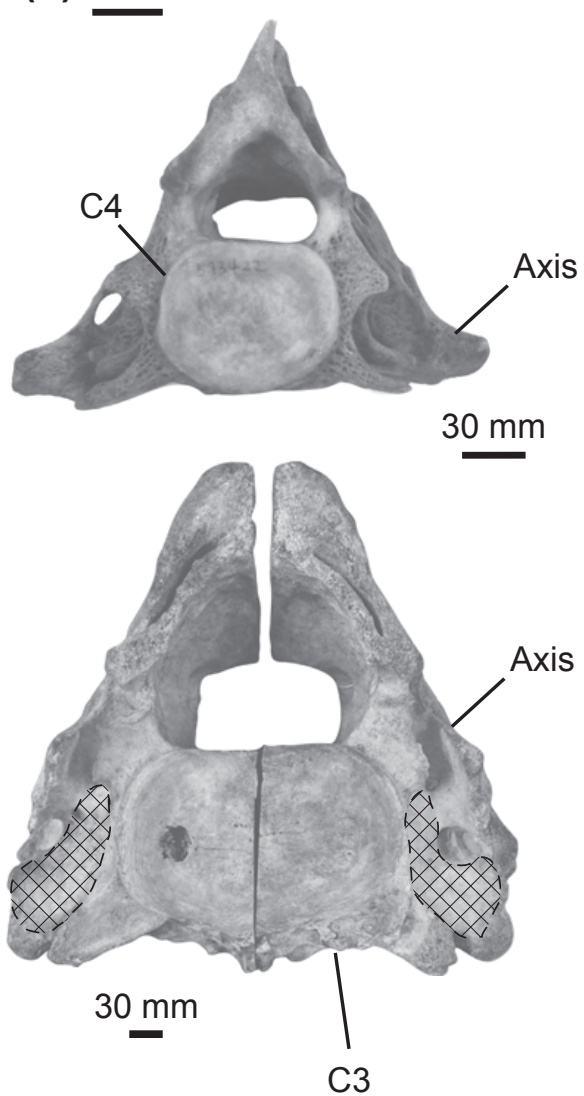

Figure 8. Comparison of muscular insertions along the atlas and axis in Messapicetus gregarius MUSM 2548 in ventral view (a) and posterior view (b); in Ninoziphius platyrostris MNHN SAS 941 in ventral view (c) and posterior view (d); in Mesoplodon densirostris USNM 593522 in ventral view (e) and posterior view (f); in Berardius sp. MNHN 1885-278. 

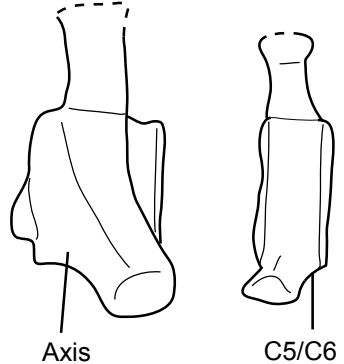

(a)

$10 \mathrm{~mm}$

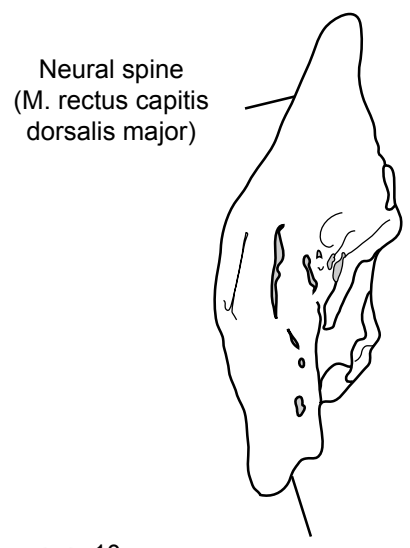

(c) ${ }^{10} \mathrm{~mm}$ Fused $\mathrm{C} 1-\mathrm{C} 7$

Neural spine (M. rectus capitis dorsalis major)

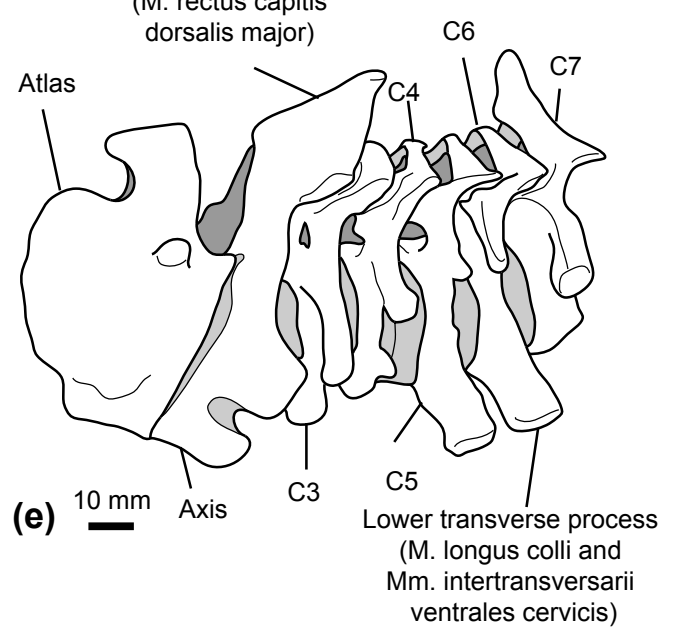

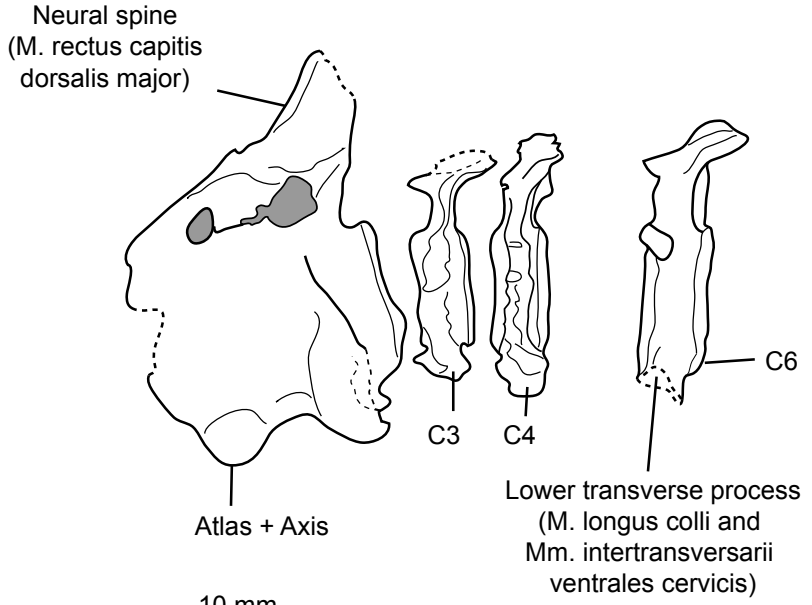

(b) $10 \mathrm{~mm}$

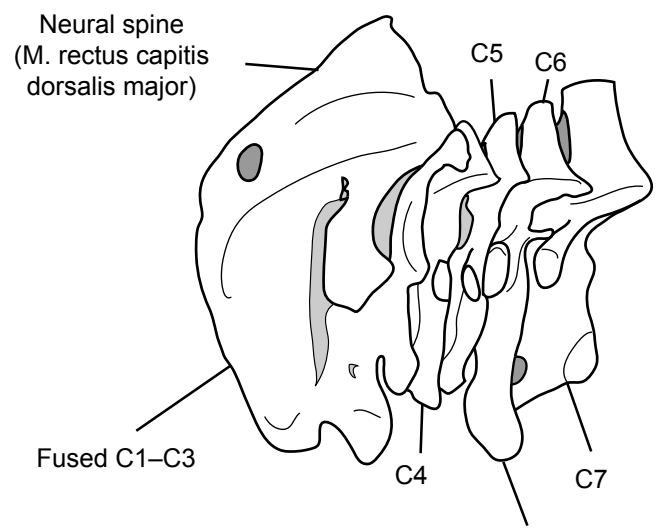

(d)
Lower transverse process (M. longus colli and $\mathrm{Mm}$. intertransversarii ventrales cervicis)

\section{Neural spine (M. rectus capitis} dorsalis major)

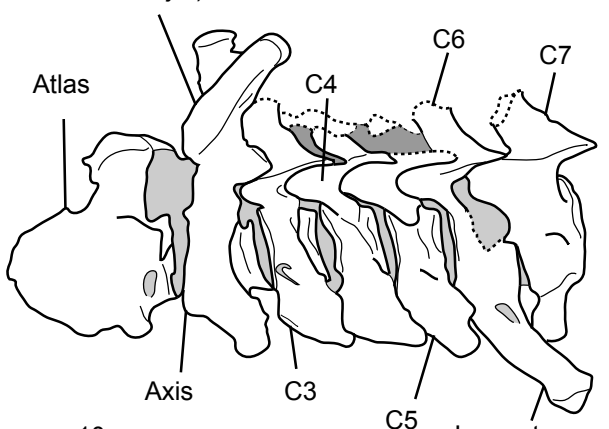

(f)

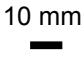

$$
\text { process }
$$

(M. longus colli and $\mathrm{Mm}$. intertransversarii ventrales cervicis)

Figure 9. Comparative reconstructions of the cervical complex in several cetaceans with neck muscle origins discussed in this paper. The reconstructions concerned Messapicetus gregarius (MUSM 2548) (a), Ninoziphius platyrostris (MNHN SAS 941) (b), Hyperoodon ampullatus (SNM CN1x) (c), Mesoplodon bidens (MNHN A14519) (d), Inia geoffrensis (SNM CN1x) (e), and Xiphiacetus cristatus (IRSNB 3240-M.361) (f). Dotted lines correspond to broken parts. 
based on its HF being posteriorly wider and dorsoventrally enlarged.

\subsubsection{Forelimb}

The relationship between forelimb measurements after logshape ratio transformation and deep-diving abilities was revealed as not significant with and without phylogenetic correction (with phylogenetic correction: $F$ ratio $=0.90638 ; p$ value $=0.5595)$. Ziphiidae, including Messapicetus gregar$i u s$, were most efficiently discriminated when PC1 $(25.60 \%)$ and PC2 (19.99\%) were combined (Fig. 12). All ziphiids exhibited a relatively elongated humerus and radius, a distally narrow humerus and radius, a shortened scapula, and a more developed deltoid tuberosity as compared to other odontocetes (Fig. 10). A similar tendency was also observed in Physeter macrocephalus (Fig. 12). The basilosaurid Dorudon atrox exhibited an even longer humerus and radius and a more developed deltoid tuberosity than extant Ziphiidae. On the other hand, the deep-diving species Delphinapterus leucas, Globicephala melas, Grampus griseus, and Pseudorca crassidens displayed the opposite tendency, with humerus and radius distally widened and a shortened humerus.

\section{Discussion}

\subsection{Neck flexibility in stem Ziphiidae}

Our reconstruction of neck muscles in the stem ziphiids Messapicetus gregarius and Ninoziphius platyrostris indicate a higher lateral and dorsoventral flexibility of the neck in both species as compared to other ziphiids of the sample. These stem ziphiids had extended insertion areas for the M. longus colli and the $\mathrm{Mm}$. intertransversarii ventrales cervicis as compared to extant ziphiids (Fig. 9) and the late Miocene crown ziphiid Nazcacetus urbinai.

In addition, the proportionally longer cervical vertebrae of long-snouted stem ziphiids compared to crown beaked whales allowed for wider lateral and dorsoventral movements.

We also interpret the low degree of fusion of the cervical vertebrae in $M$. gregarius and $N$. platyrostris as an argument in favour of a more flexible neck. Even though extant cetaceans may display intraspecific variation regarding the degree of fusion of their cervical vertebrae (Buchholtz, 2001), we argue that the low degree of fusion of the cervical vertebrae in stem ziphiids is consistent for three reasons. First, we assessed the ontogenetic stages of the studied specimen of Messapicetus gregarius as being an adult, although the degree of fusion generally increases with age in cetaceans (Buchholtz, 2001). Second, extant ziphiids generally possess at least three fused cervical vertebrae at adult age, thus contrasting with the condition in the analysed stem ziphiids (Lambert et al., 2015). Finally, the axis of M. gregarius MUSM 2548 displays an anterior articular facet for the atlas, including the odontoid process. In the dog, the absence of the odontoid process results in tilting or dorsal displacement of the axis into the vertebral canal, leading to the compression of the spinal cord (Evans and Lahunta, 2013). Therefore, the presence of this articular facet in M. gregarius would contribute to maintaining a correct articulation between the atlas and the axis in the absence of fusion between these two elements.

The more extensive fusion of the cervical vertebrae in the extant ziphiids Hyperoodon spp., Indopacetus pacificus, Tasmacetus shepherdi, and Ziphius cavirostris likely impacted lateral movements of the neck. In those species, the lower transverse process of $\mathrm{C} 6$ was also reduced, indicating a reduction of the areas of origin for both $\mathrm{M}$. longus colli and $\mathrm{Mm}$. intertransversarii cervicis. Conversely, M. bidens, $M$. densirostris, and M. grayi possess developed C6 processes, suggesting some degree of neck flexibility among crown ziphiids.

The cervical vertebra of the specimen MUSM 2548 identified as C5-C6 bears a small lower process similar in shape and development to C6 of N. platyrostris (de Muizon, 1984). This condition differs from the eurhinodelphinid Xiphiacetus cristatus, the platanistoid Otekaikea marplesi, and the basilosaurid Dorudon atrox, in which the strong and thickened lower transverse process indicate a developed origin for the M. longus colli (Fig. 9e; Lambert, 2005; Tanaka and Fordyce, 2014; Uhen, 2004). The lack of a developed lower process in C6 may suggest a less flexible neck in $N$. platyrostris and possibly $M$. gregarius compared to the aforementioned species. Yet, both $M$. gregarius and $N$. platyrostris display large insertions for the $\mathrm{M}$. longus colli and the $\mathrm{Mm}$. intertransversarii ventrales cervicis that are more developed than in any extant ziphiid.

While the spinous process of the axis was not preserved for M. gregarius, $N$. platyrostris displays a weaker spinous process compared to other extant Ziphiidae. However, a strong spinous process is present in Inia geoffrensis, an odontocete with a highly flexible neck. In $H$. ampullatus, de Muizon (1984) noted a particularly strong spinous process of the axis, most likely supporting the head.

Neck rigidity might be related to deep-diving specialization in Ziphiidae. However, differences in the degree of flexibility observed among extant ziphiids advocate for a more complex functional interpretation. Data on potential differences in swimming and feeding strategies between extant ziphiid species are currently insufficient to explain the contrasted neck morphologies observed.

\subsection{Forelimb morphology and its relation to deep diving}

Our reconstruction of the forelimb muscles of $M$. gregarius suggest no important differences with extant ziphiids. Multivariate analyses confirm this close relation, showing that $M$. gregarius and other extant ziphiids possess a relatively 

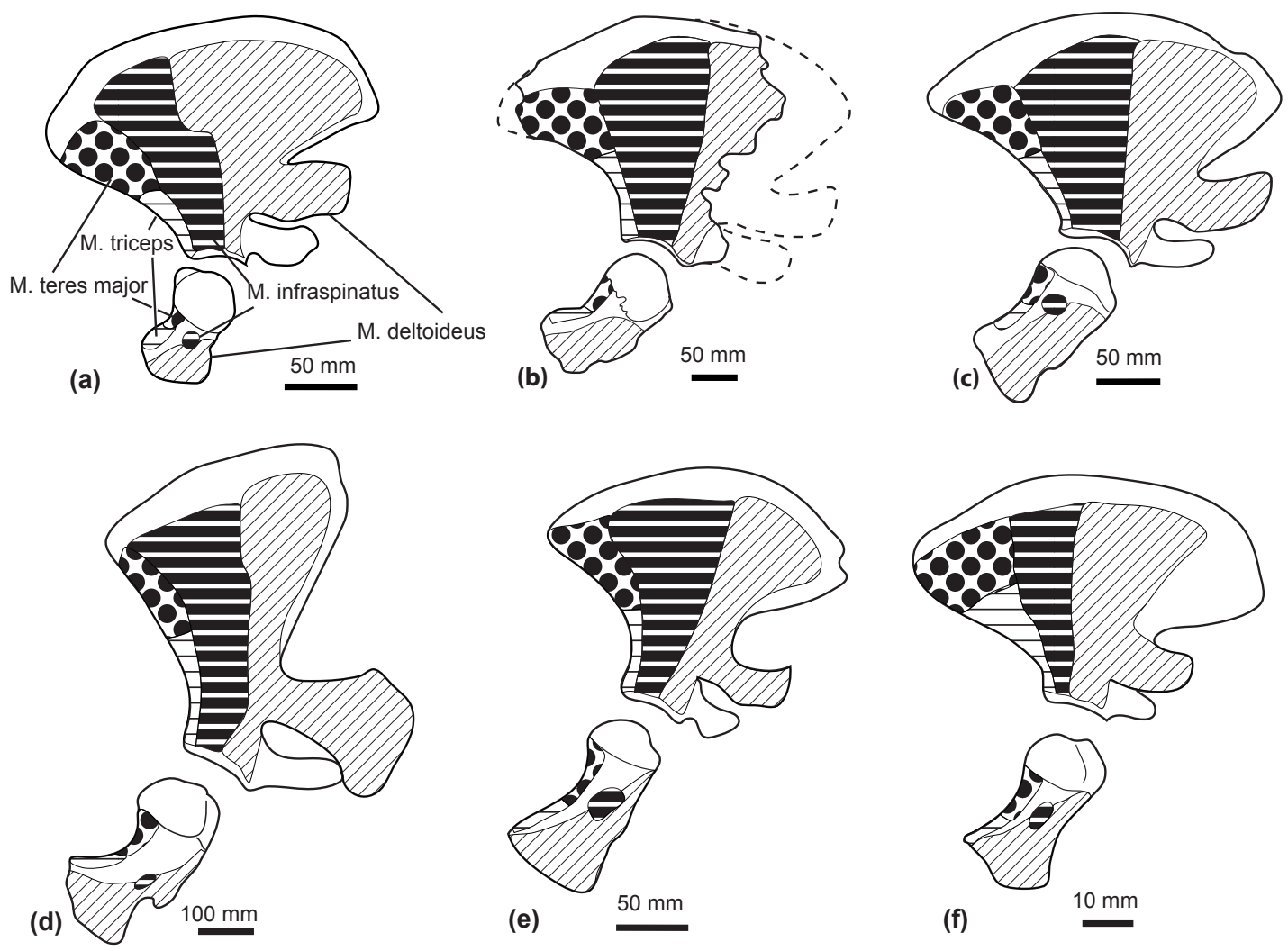

Figure 10. Comparison of the muscle origins and insertions of the scapula and humerus in lateral view in Tursiops truncatus (SNM CN2x) (a); a reconstruction of the scapula of Messapicetus gregarius (MUSM 2548) (b); Mesoplodon bidens (SNM CN4x) (c); Physeter macrocephalus (SNM CN1x) (d); Inia geoffrensis (NRS A608415) (e); Pontoporia blainvillei (SNM CN1x) (f). Insertion of the M. infraspinatus could not be assessed in $M$. gregarius. Scale $=50 \mathrm{~mm}$. Dotted lines correspond to the reconstructed parts.

similar forelimb morphology. In particular, the morphology of the radius was uniform among ziphiids, lacking the distal widening seen in many odontocetes. Elongation of the humerus in M. gregarius does not appear as obvious as we previously suggested, this feature being present in all ziphiids compared to other odontocetes. This suggests the flipper of M. gregarius to be relatively similar in shape to extant Ziphiidae. The latter display flippers that are longer than the wide, the elongated state described by Sanchez and Berta (2010).

Results of the D-PGLS indicate that the morphology of the forelimb is not associated with deep-diving abilities, suggesting that forelimb proportions cannot be used to assess deep-diving specialization in odontocetes.

Functional aspects of the flipper of ziphiids remain poorly known, but we suspect the flipper shape of $M$. gregarius to be associated with aspects of locomotion other than deep diving, like prey capture. Several cetaceans with a broad flipper, such as the killer whale Orcinus orca or the humpback whale Megaptera novaeangliae, are able to perform quick manoeuvres, helping them to catch mobile prey in the epipelagic domain (Benke, 1993; Woodward et al., 2006). With their small and elongated flipper type, extant ziphiids would probably not be as manoeuvrable, privileging speed and possibly optimizing their hydrodynamic profile instead.

\subsection{Variation in the HF and its relation to deep diving}

Our measurements of the HF were sufficient to discriminate ziphiids from other odontocetes. Furthermore, the variation in HF measurements is correlated with deep-diving specialization, thus suggesting that enlargement of the HF is a good proxy to assess deep-diving abilities. The increase in size of the HF in deep divers happens in two different ways: either by the anteroposterior and dorsoventral enlargement of the $\mathrm{HF}$ as in ziphiids, Grampus griseus, and Physeter macrocephalus, or by the anterior enlargement of the $\mathrm{HF}$ as in Globicephala melas, Monodon monoceros, and Pseudorca crassidens. Messapicetus gregarius exhibits differences in the proportions of the pterygoid sinus fossae when compared to other Ziphiidae (Fig. 11). Although less anteriorly elongated than in extant ziphiids, the HF of $M$. gregarius is also wider posteriorly, more enlarged dorsoventrally, and narrower anteriorly. 


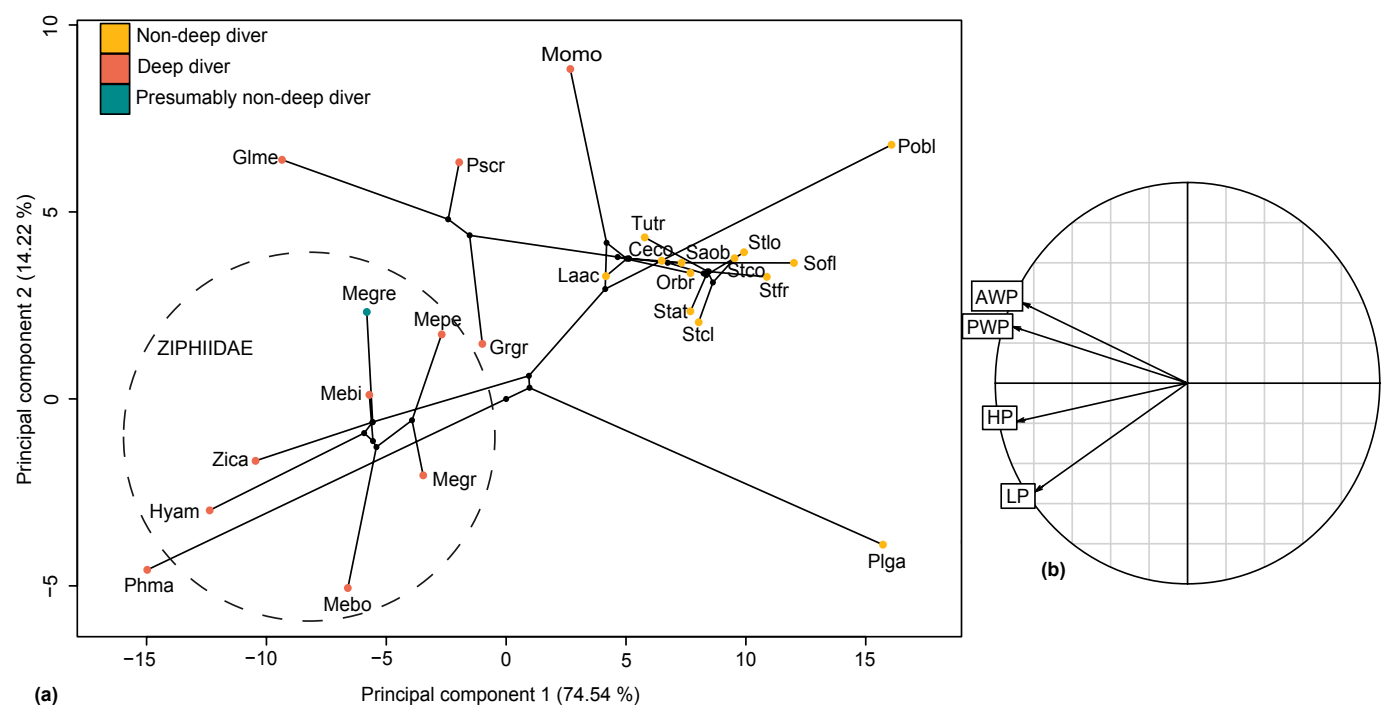

Figure 11. Phylomorphospace of the principal components 1 and 2 for the hamular fossa of the pterygoid sinus (a) and its correlation circle (b). The dotted circle delimits the Ziphiidae family. The branches represent the phylogenetic relationships between the different species. Abbreviations: Ceco: Cephalorhynchus commersonii; Glme: Globicephala melas; Grgr: Grampus griseus; Hyam: Hyperoodon ampullatus; Laac: Lagenorhynchus acutus; Mebi: Mesoplodon bidens; Megr: Mesoplodon grayi; Megre: Messapicetus gregarius; Mepe: Mesoplodon peruvianus; Momo: Monodon monoceros; Orbr:Orcaella brevirostris; Phma: Physeter macrocephalus; Pobl: Pontoporia blainvillei; Plga: Platanista gangetica; Pscr: Pseudorca crassidens; Saob:Sagmatias obscurus; Sofl: Sotalia fluviatilis; Stat: Stenella attenuata; Stcl: Stenella clymene; Stfr: Stenella frontalis; Tutr: Tursiops truncatus; Zica: Ziphius cavirostris.
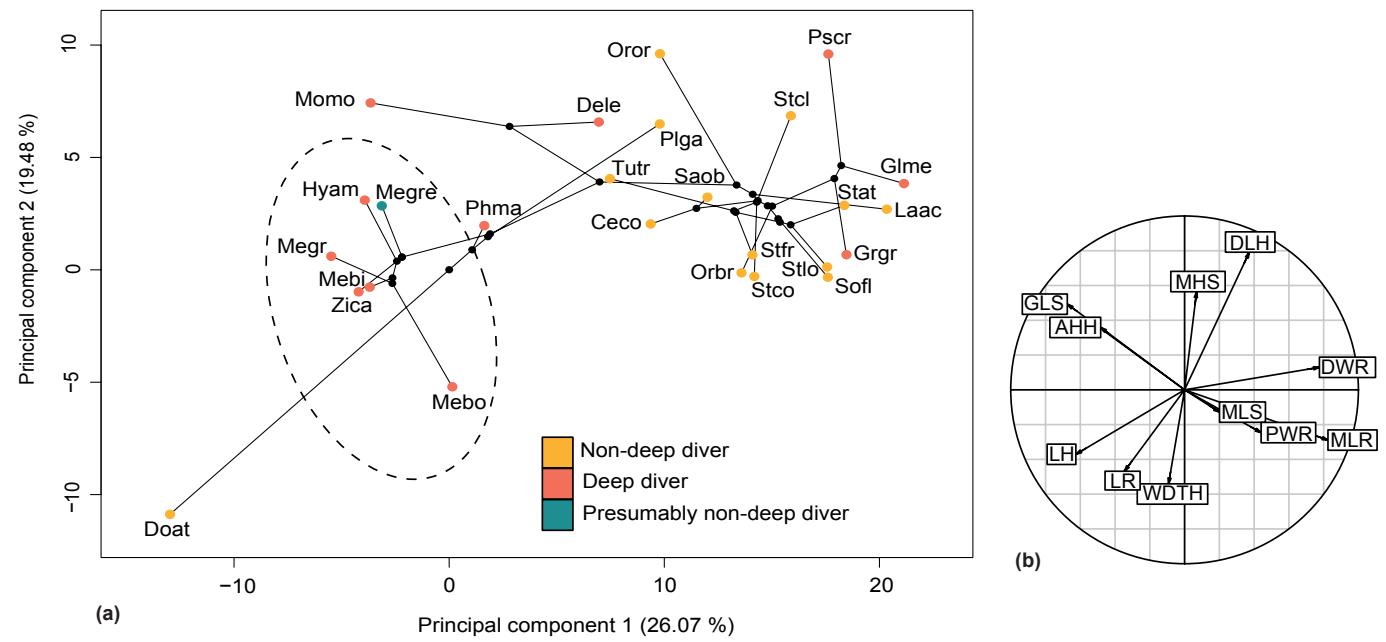

Figure 12. Phylomorphospace of the principal components 1 and 2 for the forelimb (a) and its correlation circle (b). The dotted circle delimits the Ziphiidae family. The branches represent the phylogenetic relationships between the different species. The abbreviations are the same as in Fig. 11 except for the following: Dele: Delphinapterus leucas; Doat: Dorudon atrox; Mebo:Mesoplodon bowdoini; Oror: Orcinus orca; Stco: Stenella commersonii.

Although it remains unclear if Messapicetus gregarius was able to perform regular dives beyond $1000 \mathrm{~m}$, this species was most likely capable of hearing beyond $700 \mathrm{~m}$. This new finding seemingly falsifies our former hypothesis that several long-snouted stem ziphiids were not deep divers (Lambert et al., 2015). However, several scenarios can explain this apparently contradictory result.
First, Messapicetus gregarius may have fed both in epipelagic and deeper benthopelagic grounds. While extant ziphiids are very specialized, other deep divers are more opportunistic. For example, Pseudorca crassidens and Delphinapterus leucas feed on a wide variety of prey at different depths from 100 up to $700 \mathrm{~m}$ in the case of P. crassidens and $900 \mathrm{~m}$ for D. leucas (Martin et al., 1998; O'Corry-Crowe, 
2009; Oleson et al., 2010; Richard et al., 2001). A more flexible feeding behaviour may have occurred in stem ziphiids like $M$. gregarius. Different individuals in the species may also have different preferences. In Megaptera novaeangliae, maternal females favour shallower waters with their calves, perhaps to protect them from sexually active males or to avoid turbulent offshore sea conditions and/or predators (Smultea, 1994). In the case of Messapicetus gregarius, males and females have been identified at Cerro Colorado based on secondary sexual characters (i.e., intraspecific variation in tusk development and surrounding structures; Lambert et al., 2010a). The co-occurrence of male and female mature specimens and a calf at the same location suggests that $M$. gregarius did not follow the same strategy as $M$. novaeangliae, but does not discard a seasonal use of this basin as a potential nursery ground.

A second plausible explanation for the enlarged HF of $M$. gregarius is predation avoidance. Three potential predators for M. gregarius were present at Cerro Colorado during the late Miocene: the sperm whale Livyatan melvillei and the giant sharks Cosmopolitodus spp. and Carcharocles megalodon, the latter being believed to have fed on small-sized baleen whales and pinnipeds (Collareta et al., 2017; Lambert et al., 2010b; Landini et al., 2017a). M. gregarius may have performed deep dives to avoid these two predators. This strategy is already suspected in extant beaked whales based on several mass strandings of Mesoplodon densirostris and Ziphius cavirostris directly related to naval exercises involving mid-frequency active sonars (Amico et al., 2009; Cox et al., 2006; Filadelfo et al., 2009). It is generally accepted that the sound exposure forces beaked whales to alter their own diving behaviour, causing a decompression syndrome (Cox et al., 2006; Tyack et al., 2011). Zimmer and Tyack (2007) noticed the resemblance between the tonal mid-frequencies used and the calls of killer whales (Orcinus orca), suggesting that ziphiids try to avoid the latter. Furthermore, two studies were able to trigger this avoidance behaviour in Mesoplodon densirostris by exposing the animals to killer whale calls. A few cases of active predation have also been reported, suggesting that this avoidance strategy is not perfect (Wellard et al., 2016). One flaw of this hypothesis is that depth estimates for the P1 sequence of the Pisco Formation at Cerro Colorado do not exceed some tens of metres, thus limiting the diving possibilities of the specimens living in the area (Claudio Di Celma, personal communication, 2017; see also depth estimates in Landini et al., 2017a, b). Therefore, this scenario is only possible if $M$. gregarius did not limit itself to the epipelagic grounds where it is currently found.

A last explanation for the enlargement of the HF in M. gregarius is a reversion to an epipelagic habitat in this species. This scenario implies the specialization for deep diving to be more ancestral among ziphiids, with a secondary change in habitat for M. gregarius. Enlargement of the HF in this species would therefore be explained because of phylogenetic inertia. Our former hypothesis proposed a unique ac- quisition of the deep-diving behaviour in Ziphiidae between long-snouted stem ziphiids and crown ziphiids (Lambert et al., 2015). However, a recent phylogenetic analysis suggested that the ecological shift to deep diving occurred two times in the family with the inclusion of deep-diving forms in the Messapicetus clade (Bianucci et al., 2016c). Using this new phylogeny, our former hypothesis stated in Lambert et al. (2015) is no longer the most parsimonious, further reducing the amount of indirect evidence in favour of Messapicetus as an exclusively epipelagic form, although several other lines of evidence indicate that a shallow coastal environment represented an important part of its home range.

A combination of these features is also possible. Currently, we are unable to favour one hypothesis or the other.

\section{Conclusions}

Ziphiid postcranial elements are rare in the fossil record (Bianucci et al., 2016a; de Muizon, 1984; Ramassamy, 2016). As a result, the description of cervical vertebrae and forelimb elements of the stem ziphiid Messapicetus gregarius from the late Miocene of Peru yields new information about the anatomy and ecology of extinct Ziphiidae.

Our reconstruction of the neck muscles of $M$. gregarius and Ninoziphius platyrostris suggests that these stem ziphiids had a flexible neck able to make stronger dorsoventral and lateral movements than most extant ziphiids. The absence of fusion of the neck vertebrae in one specimen of $M$. gregarius is interpreted as a typical characteristic of the species because of (1) the adult ontogenetic stage of the specimen, (2) the presence of an odontoid process allowing for a precise articulation between the axis and the atlas, and (3) the fusion of the cervicals being present in all other ziphiid species examined. The presence of larger transverse processes of C6 in some species of Mesoplodon and the interspecific variation in the degree of fusion of the cervical vertebrae of extant ziphiids indicate various degrees of flexibility in the neck in the latter.

The proportions of the forelimb bones of $M$. gregarius are similar to those of extant ziphiids. We estimate the flipper shape of M. gregarius to resemble the shape in extant ziphiids. Changes in the forelimb morphology in Ziphiidae are not related to deep-diving abilities when phylogenetic context is taken into account and suggest that other proxies should be used to infer diving abilities in odontocetes.

Finally, our measurements of the hamular fossa of the pterygoid sinus are sufficient to evaluate deep-diving abilities in odontocetes with and without phylogenetic correction. The enlargement of the hamular fossa is also present in Messapicetus gregarius, implying that this species was able to hear at least beyond $700 \mathrm{~m}$. We propose several explanations to rectify this result with other evidence suggesting that M. gregarius was an epipelagic predator: (1) this species was perhaps more opportunistic than extant ziphiids and fed at 
different depths; (2) it performed deep dives to avoid potential predators; (3) or the enlarged HF in $M$. gregarius corresponds to an ancestral adaptation not matching the epipelagic habitat of this species (3). A combination of any of these different scenarios is also plausible.

Data availability. Dataset 1: R script used for the analysis.

Dataset 2: complete set of linear measurements used in the present study.

Dataset 3: list of supplementary references for the maximum depth records.

All data information can be found at https://doi.org/10.6084/m9. figshare.5259157.v2.

Author contributions. All authors took part in the fieldwork and collected field data. OL, GB, MU, and BR identified and interpreted the ziphiid remains. Measurements were taken by $\mathrm{AC}, \mathrm{GB}, \mathrm{OL}$, and BR. Photos were taken by BR, AC, and GB. BR wrote the paper and performed the analyses. All authors commented on the paper at all stages.

Competing interests. The authors declare that they have no conflict of interest.

Special issue statement. This article is part of the special issue "Secondary adaptation of tetrapods to life in water - Proceedings of the 8th International Meeting, Berlin 2017". It is a result of the 8th International Meeting on the Secondary Adaptation of Tetrapods to Life in Water, Berlin, Germany, 3-8 April 2017.

Acknowledgements. We thank the following colleagues for kindly allowing us to access some of the comparative material we used in this study: Morten T. Olsen and Daniel K. Johansson for access to the SNM collection, S. Bruaux for the IRSNB collection, Christian de Muizon and Christine Lefèvre for the MNHN collections, Chiara Sorbini for the MSNUP collections, and Charles Potter for the USNM collections. We are indebted to Klaas Post for his help in the field to collect and identify the specimens.

We thank Walter Aguirre, who collected the specimens, and Walter Aguirre, Rodolfo Salas-Gismondi, and Rafael Varas-Malca, who prepared the specimens and provided assistance during our stay at the MUSM.

BR also wishes to thank his supervisors Mette E. Steeman and Thomas Pape for the advice they provided on the paper, which is part of his PhD thesis. He also thanks Andrew Steward from the Te Papa Tongarewa Museum of New Zealand for the photographs of Tasmacetus shepherdi he kindly provided. Finally, he thanks Pavel Gol'din, Thomas Guillerme, and Nina M. Jakobsen for the help they provided for the statistical analyses.

We thank the reviewers, Annalisa Berta and Mark D. Uhen, and the Chief Editor Florian Witzmann, who provided relevant comments and improved the quality of the paper.
The research was partially supported by a grant from the Dansk Slots- og Kulturstyrelsen (FORM.2016-0021) to B. Ramassamy, a grant from the Italian Ministero dell'Istruzione dell'Università e della Ricerca (PRIN project 2012YJSBMK), and by a National Geographic Society Committee for Research Exploration grant (9410-13), both to G. Bianucci.

Edited by: Florian Witzmann

Reviewed by: Annalisa Berta and Mark D. Uhen

\section{References}

Adams, D. C.: A method for assessing phylogenetic least squares models for shape and other high-dimensional multivariate data, Evolution, 68, 2675-2688, 2014.

Adams, D. C. and Otarola-Castillo, E.: geomorph: an R package for the collection and analysis of geometric morphometric shape data, Methods in Eology and Evolution, 4, 393-399, 2013.

Amico, A., D’Spain, G., Fernández, A., Finneran, J., Gentry, R., Gerth, W., Gulland, F., Hildebrand, J., Houser, D., Hullar, T., Jepson, P. D., Ketten, D., MacLeod, C. D., Miller, P., Moore, S., Mountain, D. C., Palka, D., Ponganis, P., Rommel, S., Rowles, T., Taylor, B., Tyack, P., Wartzok, D., Gisiner, R., Mead, J., and Benner, L.: Understanding the impacts of anthropogenic sound on beaked whales, Journal of Cetacean Research and Management, 7, 177-187, 2006.

Amico, A., Gisiner, R. C., Ketten, D. R., Hammlock, J. A., Johnson, C., Tyack, P. L., and Mead, J.: Beaked Whale Strandings and Naval Exercises, Aquat. Mamm., 35, 452-472, 2009.

Benke, H.: Investigations on the osteology and the functional morphology of the flipper of whales and dolphins (Cetacea), Investigations on Cetacea, 24, 9-252, 1993.

Bianucci, G., Landini, W., and Varola, A.: Relationships of Messapicetus longirostris (Cetacea, Ziphiidae) from the Miocene of South Italy, Bolletino della Società Paleontologica Italiana, 33, 231-241, 1994.

Bianucci, G., Post, K., and Lambert, O.: Beaked whale mysteries revealed by seafloor fossils trawled off South Africa, S. Afr. J. Sci., 104, 140-142, 2008.

Bianucci, G., Lambert, O., and Post, K.: High concentration of long-snouted beaked whales (genus Messapicetus) from the Miocene of Peru, Palaeontology, 53, 1077-1098, https://doi.org/10.1111/j.1475-4983.2010.00995.x, 2010.

Bianucci, G., Miján, I., Lambert, O., Post, K., and Mateus, O.: Bizarre fossil beaked whales (Odontoceti, Ziphiidae) fished from the Atlantic Ocean floor off the Iberian Peninsula, Geodiversitas, 35, 105-153, https://doi.org/10.5252/g2013n1a6, 2013.

Bianucci, G., Collareta, A., Post, K., Varola, A., and Lambert, O.: A new record of Messapicetus from the Pietra Leccese (Late Miocene, Southern Italy): antitropical distribution in a fossil beaked whale (Cetacea, Ziphiidae), Rivista Italiana di Paleontologia e Stratigrafia (Research In Paleontology and Stratigraphy), 122, 2016a.

Bianucci, G., Di Celma, C., Landini, W., Post, K., Tinelli, C., de Muizon, C., Gariboldi, K., Malinverno, E., Cantalamessa, G., Gioncada, A., Collareta, A., Salas-Gismondi, R., Varas, R., Stucchi, M., Urbina, M., and Lambert, O.: Distribution of fossil marine vertebrates in Cerro Colorado, the type locality of the giant 
raptorial sperm whale Livyatan melvillei (Miocene, Pisco Formation, Peru), Journal of Maps, 12, 543-557, 2016b.

Bianucci, G., Di Celma, C., Urbina, M., and Lambert, O.: New beaked whales from the late Miocene of Peru and evidence for convergent evolution in stem and crown Ziphiidae (Cetacea, Odontoceti), PeerJ, 4, e2479, https://doi.org/10.7717/peerj.2479, 2016c.

Buchholtz, E. A.: Vertebral osteology and swimming style in living and fossil whales (Order: Cetacea), J. Zool., 253, 175-190, 2001.

Clarke, M. R.: Cephalopods as prey. III. Cetaceans, T. Roy. Soc. London B, 351.1343, 1053-1065, https://doi.org/10.1098/rstb.1996.0093, 1996.

Collareta, A., Landini, W., Lambert, O., Post, K., Tinelli, C., Di Celma, C., Panetta, D., Tripodi, M., Salvadori, P. A., Caramella, D., Marchi, D., Urbina, M., and Bianucci, G.: Piscivory in a Miocene Cetotheriidae of Peru: first record of fossilized stomach content for an extinct baleen-bearing whale, The Science of Nature, 102, 1-12, 2015.

Collareta, A., Lambert, O., Landini, W., Di Celma, C., Malinverno, E., Varas-Malca, R., Urbina, M., and Bianucci, G.: Did the giant extinct shark Carcharocles megalodon target small prey? Bite marks on marine mammal remains from the late Miocene of Peru, Palaeogeogr. Palaeoclimatol. Palaeoecol., 469, 84-91, 2017.

Cooper, L. N., Dawson, S. D., Reidenberg, J. S., and Berta, A.: Neuromuscular anatomy and evolution of the cetacean forelimb, The Anatomical Record, 290, 1121-1137, 2007.

Cox, T. M., Ragen, T. J., Read, A. J., Vos, E., Baird, R. W., Balcomb, K. Barlow, J., Caldwell, J., Cranford, T., Crum, L., D’Amico, A., D’Spain, G., Fernández, A., Finneran, J., Gentry, R., Gerth, W., Gulland, F., Hildebrand, J., Houser, D., Hullar, T., Jepson, P. D., Ketten, D., MacLeod, C. D., Miller, P., Moore, S., Mountain, D. C., Palka, D., Ponganis, P., Rommel, S., Rowles, T., Taylor, B., Tyack, P., Wartzok, D., Gisiner, R., Mead, J., and Benner, L.: Understanding the impacts of anthropogenic sound on beaked whales, Journal of Cetacean Research and Management, 7, 177$187,2006$.

Cranford, T. W., Mckenna, M. F., Soldevilla, M. S., Wiggins, S. M., Goldbogen, J. A., Shadwick, R. E., Krysl, P., St. Leger, J. A., and Hildebrand, J. A.: Anatomic geometry of sound transmission and reception in Cuvier's beaked whale (Ziphius cavirostris), The Anatomical Record, 291, 353-378, 2009.

Dalebout, M. L., Baker, S. C., Steel, D., Thompson, K., Robertson, K. M., Chivers, S. J., Perrin, W. F., Goonatilake, M., Anderson, R. C., Mead, J. G., Potter, C. W., Thompson, L., Jupiter, D., and Yamada, T. K.: Resurrection of Mesoplodon hotaula Deraniyagala 1963: A new species of beaked whale in the tropical Indo-Pacific, Mar. Mammal Sci., 30, 1081-1108, https://doi.org/10.1111/mms.12113, 2014.

de Muizon, C.: Les vertébrés fossiles de la Formation Pisco (Pérou). deuxième partie: les Odontocètes (Cetacea, Mammalia) du Pliocène inférieur de Sud-Sacaco, Travaux de l'Institut Français d'Etudes Andines, 27, 1-188, 1984.

Di Celma, C., Malinverno, E., Gariboldi, K., Gioncada, A., Rustichelli, A., Pierantoni, P., Landini, W., Bosio, G., Tinelli, C., and Bianucci, G.: Stratigraphic framework of the late Miocene to Pliocene Pisco Formation at Cerro Colorado (Ica Desert, Peru), Journal of Maps, 12, 1-15, 2016.
Di Celma, C., Malinverno, E., Bosio, G., Collareta, A., Gariboldi, K., Gioncada, A., Molli, G., Basso, D., Varas-Malca, R. M., and Pierantoni, P. P.: Sequence stratigraphy and paleontology of the Upper Miocene Pisco Formation along the western side of the lower Ica Valley (Ica Desert, Peru), Rivista Italiana di Paleontologia e Stratigrafia, 123, 255-273, 2017.

Evans, H. E. and de Lahunta, A.: Miller's Anatomy of the Dog, Elsevier Health Sciences, 2013.

Felsenstein, J.: Phylogenies and the comparative method, American Naturalist, 125, 1-15, 1985.

Filadelfo, R., Mintz, J., Michlovich, E., D’Amico, A., Tyack, P. L., and Ketten, D. R.: Correlating Military Sonar Use with Beaked Whale Mass Strandings: What Do the Historical Data Show?, Aquat. Mamm., 35, 435-444, https://doi.org/10.1578/AM.35.4.2009.435, 2009.

Fitzgerald, E. M.: A late Oligocene waipatiid dolphin (Odontoceti: Waipatiidae) from Victoria, Australia, Memoirs of Museum Victoria, 74, 117-136, 2016.

Fox, J. and Weisberg, S.: An $\{\mathrm{R}\}$ Companion to Applied Regression, 2nd ed., Sage, Thousand Oaks CA, 2011.

Fraser, F. C. and Purves, P. E.: Hearing in cetaceans: evolution of the accessory air sacs and the structure and function of the outer and middle ear in recent cetaceans, Bulletin of the British Museum (Natural History), Zoology, 1960.

Galatius, A. and Kinze, C. C.: Ankylosis patterns in the postcranial skeleton and hyoid bones of the harbour porpoise (Phocoena phocoena) in the Baltic and North Sea, Can. J. Zool., 81, 18511861, 2003.

Gariboldi, K., Bosio, G., Malinverno, E., Gioncada, A., Di Celma, C., Villa, I. M., Urbina, M., and Bianucci, G.: Biostratigraphy, geochronology and sedimentation rates of the upper Miocene Pisco Formation at two important marine vertebrate fossilbearing sites of southern Peru, Newsletters on Stratigraphy, 2017.

Gioncada, A., Collareta, A., Gariboldi, K., Lambert, O., Di Celma, C., Bonaccorsi, E., Urbina, M., and Bianucci, G.: Inside baleen: Exceptional microstructure preservation in a late Miocene whale skeleton from Peru, Geology, 44, 839-842, 2016.

Heyning, J. E. and Mead, J. G.: Suction feeding in beaked whales: morphological and observational evidence, Contributions in Science, Natural History Museum of Los Angeles County, 464, 1$12,1996$.

Hooker, S. K. and Baird, R. W.: Deep-diving behaviour of the northern bottlenose whale, Hyperoodon ampullatus (Cetacea: Ziphiidae), P. Roy. Soc. London B, 266, 671-676, 1999.

Johnson, M., Madsen, P. T., Zimmer, W. M. X., De Soto, N. A., and Tyack, P. L.: Beaked whales echolocate on prey, P. Roy. Soc. London B, 271, S383-S386, 2004.

Lambert, O.: Phylogenetic affinities of the long-snouted dolphin Eurhinodelphis (Cetacea, Odontoceti) from the Miocene of Antwerp, Belgium, Palaeontology, 48, 653-679, 2005.

Lambert, O. and Louwye, S.: Archaeoziphius microglenoideus, a new primitive beaked whale (Mammalia, Cetacea, Odontoceti) from the middle Miocene of Belgium, J. Vertebr. Paleontol., 26, 182-191, https://doi.org/10.1671/02724634(2006)26[182:AMANPB]2.0.CO;2, 2006.

Lambert, O., Bianucci, G., and Post, K.: A new beaked whale (Odontoceti, Ziphiidae) from the middle Miocene of Peru, J. Vertebr. Paleontol., 29, 910-922, https://doi.org/10.1671/039.029.0304, 2009. 
Lambert, O., Bianucci, G., and Post, K.: Tusk-bearing beaked whales from the Miocene of Peru: sexual dimorphism in fossil ziphiids?, J. Mammal., 91, 19-26, https://doi.org/10.1644/08MAMM-A-388R1.1, 2010a.

Lambert, O., Bianucci, G., Post, K., de Muizon, C., SalasGismondi, R., Urbina, M., and Reumer, J.: The giant bite of a new raptorial sperm whale from the Miocene epoch of Peru, Nature, 466, 105-108, 2010b.

Lambert, O., de Muizon, C., and Bianucci, G.: The most basal beaked whale Ninoziphius platyrostris Muizon, 1983: clues on the evolutionary history of the family Ziphiidae (Cetacea: Odontoceti), Zool. J. Linn. Soc. Lond., 167, 569-598, https://doi.org/10.1111/zoj.12018, 2013.

Lambert, O., Collareta, A., Landini, W., Post, K., Ramassamy, B., Di Celma, C., Urbina, M., and Bianucci, G.: No deep diving: evidence of predation on epipelagic fish for a stem beaked whale from the Late Miocene of Peru, Proceedings of the Royal Society B, 282, 20151530, 2015.

Landini, W., Altamirano-Sierra, A., Collareta, A., Di Celma, C., Urbina, M., and Bianucci, G.: The late Miocene elasmobranch assemblage from Cerro Colorado (Pisco Formation, Peru), J. S. Am. Earth Sci., 73, 168-190, 2017a.

Landini, W., Collareta, A., Pesci, F., Di Celma, C., Urbina, M., and Bianucci, G.: A secondary nursery area for the copper shark Carcharhinus brachyurus from the late Miocene of Peru, J. S. Am. Earth Sci., 78, 164-174, https://doi.org/10.1016/j.jsames.2017.07.003, 2017b.

MacLeod, C. D., Colin, D., Santos, M. B., and Perce, G. J.: Review of data on diets of beaked whales: evidence of niche separation and geographic segregation, Journal of the Marine Biological Association of the UK, 83, 651-665, https://doi.org/10.1017/S0025315403007616h, 2003.

Marcus, L. F.: Chapter 4: Traditional Morphometrics, in: Proceedings of the Michigan morphometrics workshop, edited by: Rohlf, F. J. and Bookstein, F. L., University of Michigan Museum of Zoology, 1990.

Martin, A. R., Smith, T. G., and Cox, O. P.: Dive form and function in belugas Delphinapterus leucas of the eastern Canadian High Arctic, Polar Biol., 20, 218-228, 1998.

Martins, E. P. and Hansen, T. F.: Phylogenies and the comparative method: a general approach to incorporating phylogenetic information into the analysis of interspecific data, American Naturalist, 149, 646-667, 1997.

Marx, F., Lambert, O., and Uhen, M. D.: Cetacean Paleobiology, John Wiley \& Sons, 2016.

McGowen, M. R., Spaulding, M., and Gatesy, J.: Divergence date estimation and a comprehensive molecular tree of extant cetaceans, Mol. Phylogenet. Evol., 53, 891-906, 2009.

Mead, J. G., Walker, W. A., and Houck, W. J.: Biological observations on Mesoplodon carlhubbsi (Cetacea: Ziphiidae), Smithsonian Institution Press, 1-25, 1982.

Minamikawa, S., Iwasaki, T., and Kishiro, T.: Diving behaviour of a Baird's beaked whale, Berardius bairdii, in the slope water region of the western North Pacific: first dive records using a data logger, Fish. Oceanogr., 16, 573-577, 2007.

Mosimann, J. E.: Size allometry: size and shape variables with characterizations of the lognormal and generalized gamma distributions, J. Am. Stat. Assoc., 65, 930-945, 1970.
O'Corry-Crowe, G. M.: Beluga whale (Delphinapterus leucas), in: Encyclopedia of marine mammals, 2nd edition ed., Academic Press, United States of America, 108-112, 2009.

Oleson, E. M., Boggs, C. H., Forney, K. A., Hanson, M. B., Kobayashi, D. R., Taylor, B. L., Wade, B. R., and Ylitalo, G. M.: Status review of Hawaiian insular false killer whales (Pseudorca crassidens) under the Endangered Species Act, NOAA Technical Memorandum NMFS, 140, 2010.

Orme, D.: The caper package: comparative analysis of phylogenetics and evolution in R, R package version 5, 2013.

Parham, J. F. and Pyenson, N. D.: New sea turtle from the Miocene of Peru and the iterative evolution of feeding ecomorphologies since the Cretaceous, J. Paleontol., 84, 231-247, 2010.

Ramassamy, B.: Description of a new long-snouted beaked whale from the Late Miocene of Denmark: evolution of suction feeding and sexual dimorphism in the Ziphiidae (Cetacea: Odontoceti), Zool. J. Linn. Soc. Lond., 178, 381-409, 2016.

Ramassamy, B., Lambert, O., Collareta, A., Urbina, G., and Bianucci, G.: Description of the skeleton of the fossil beaked whale Messapicetus gregarius, searching potential proxies for deep diving abilities, figshare, https://doi.org/10.6084/m9.figshare.5259157.v2, 2018.

R Development Core Team: R: A language and environment for statistical computing, $\mathrm{R}$ foundation for Statistical Computing, Vienna, Austria, 2015.

Revell, L. J.: Size-correction and principal components for interspecific comparative studies, Evolution, 63, 3258-3268, 2009.

Revell, L. J.: phytools: an R package for phylogenetic comparative biology (and other things), Methods in Eology and Evolution 3, 217-223, 2012.

Richard, P. R., Heide-Jørgensen, M. P., Orr, J. R., Dietz, R., and Smith, T. G.: Summer and Autumn Movements and Habitat Use by Belugas in the Canadian High Arctic and Adjacent Areas, Arctic, 54, 207-222, 2001.

Rommel, S., Costidis, A., Fernandez, A., Jepson, P., Pabst, D., McLellan, W., Houser, D., Cranford, T., Van Helden, A., and Allen, D.: Elements of beaked whale anatomy and diving physiology and some hypothetical causes of sonar-related stranding, Journal of Cetacean Research and Management, 7, 189-209, 2006.

Sanchez, J. A. and Berta, A.: Comparative anatomy and evolution of the odontocete forelimb, Mar. Mamm. Sci., 26, 140-160, 2010.

Schorr, G. S., Falcone, E. A., Moretti, D. J., and Andrews, R. D.: First long-term behavioral records from Cuvier's beaked whales (Ziphius cavirostris) reveal record-breaking dives, PloS one, 9, e92633, https://doi.org/10.1371/journal.pone.0092633, 2014.

Schulte, H. v. W.: Anatomy of a Foetus of Balaenoptera borealis, New York, 1916.

Stucchi, M., Varas-Malca, R. M., and Urbina-Schmitt, M.: New Miocene sulid birds from Peru and considerations on their Neogene fossil record in the Eastern $\mathrm{Pa}$ cific Ocean, Acta Palaeontologica Polonica, 61, 417-427, https://doi.org/10.4202/app.00170.2015, 2016.

Smultea, M. A.: Segregation by humpback whale (Megaptera novaeangliae) cows with a calf in coastal habitat near the island of Hawaii, Can. J. Zool., 72, 805-811, 1994.

Tanaka, Y. and Fordyce, R. E.: Fossil Dolphin Otekaikea marplesi (Latest Oligocene, New Zealand) Expands the Morphological 
and Taxonomic Diversity of Oligocene Cetaceans, PloS one, 9, e107972, https://doi.org/10.1371/journal.pone.0107972, 2014.

Tyack, P. L., Johnson, M., Soto, N. A., Sturlese, A., and Madsen, P. T.: Extreme diving of beaked whales, J. Exp. Biol., 209, 42384253, 2006.

Tyack, P. L., Zimmer, W. M. X., Moretti, D., Southall, B. L., Claridge, D. E., Durban, J. W., Clark, C. W., Amico, A., DiMarzio, N., Jarvis, S., McCarthy, E., Morrissey, R., Ward, J., and Boyd, I. L.: Beaked Whales Respond to Simulated and Actual Navy Sonar, PLoS ONE, 6, e17009, https://doi.org/10.1371/journal.pone.0017009, 2011.

Uhen, M.: Form, function, and anatomy of Dorudon atrox (Mammalia, Cetacea): an archeocete from the middle to late Eocene of Egypt. University of Michigan Papers on Paleontology, 34, $1-222,2004$.
Wellard, R., Lightbody, K., Fouda, L., Blewitt, M., Riggs, D., and Erbe, C.: Killer Whale (Orcinus orca) Predation on Beaked Whales (Mesoplodon spp.) in the Bremer Sub-Basin, Western Australia, PloS one, 11, e0166670, https://doi.org/10.1371/journal.pone.0166670, 2016.

Woodward, B. L., Winn, J. P., and Fish, F. E.: Morphological specializations of baleen whales associated with hydrodynamic performance and ecological niche, J. Morphol., 267, 1284-1294, 2006.

Zimmer, W. M. X. and Tyack, P.: Repetitive shallow dive pose decompression risk in deep-diving beaked whales, Mar. Mammal Sci., 23, 888-925, 2007. 